NBER WORKING PAPERS SERTES

MEASURES OF PRICFS AND PRICE

COMPETITIVENESS IN INIERNATITONAL

TRADE IN MANUFACIURED GOODS

Robert E. Lipsey

Linda Molinari

Irving B. Kravis

Working Paper No. 3442

NATIONAL BUREAU OF EOONOMIC RESEARCH

1050 Massachusetts Avenue

Cambridge, MA 02138

September 1990

This paper is part of NBER's research program in International studies. AnY opinions expressed are those of the authors and not those of the National Bureau of Economic Research. 
NBER Working Paper \#3442

September 1990

MEASURES OF PRICES AND FRICE COMPETITIVENESS

IN INTERNATIONAL TRADE IN MANUFACIURED COONS

\section{ABSTRACT}

The purpose of this paper is to present, and to explain the construction of, a set of price indexes relating to international trade in manufactured goods. These include:

1. Indexes of export prices for the U.S., Germany, and Japan, based on their own weights, and indexes of competitors' prices for each of those countries based on the same set of weights;

2. Indexes of domestic prices for the U.S., Germany, and Japan based on export weights;

3. Indexes for developed country exports of mamufactures based on weights of developed country exports of manufactures to developing countries and of total developed country exports of manufactures, and indexes for exports of the U.S., Germany, and Japan on the same sets of weights.

The indexes for developed country exports make use of a method for estimating missing prices that takes acoount not only of contemporaneous price changes in the same country within the same commodity groups, but also of price changes for the particular commodity in other countries.

comparisons are made between movements of domestic and export prices and between price indexes based on weights of early and late base years. In addition, an attempt is made to correct the price indexes for changes in the quality of some manufactured goods not usually taken acoount of in measures of export or import prices.

Robert E. I.ipsey

Queens college and Graduate center, CUNY

Flushing, NY 11367 and

NBER

269 Mercer Street

New York, NY 10003
Iinda Molinari

University Computer

Center, CUNY

555 West 57 Street

New York, NY 10019
Irving B. Kravis

University of Pennsylvania

Department of Economics

Philadelphia, PA 19104

and

NBER

269 Nercer Street

New York, NY 10003 


\title{
MEASURES OF PRICES AND PRICE COMPETITIVENESS IN INTERNATIONAL \\ TRADE IN MANUFACTURED GOODS*
}

\author{
Robert E. Lipsey \\ Linda Molinar $\mathbf{i}$ \\ Irving B. Kravis
}

\section{INTRODUCTION}

Our purpose in this paper is to explain the construction of a set of price indexes relating to international trade in manufactured goods. The indexes are intended to be free of some of the defects of existing measures and more suitable for the calculation of changes in quantities traded and for the analysis of the relations between prices and quantities.

Measures of the prices of manufactured goods are a weak link in empirical studies of international trade. While most authors have accepted the existing indexes for primary products as reasonably accurate and representative, quite a few have been skeptical about the data for manufactured goods prices. Their deficiencies affect studies of competitiveness, of real exchange rates, of income elasticities of demand, of price and substitution elasticities, of the terms of trade, and of the supply of exports.

\footnotetext{
* We are indebted to Catherine Mann and J. David Richardson for many valuable comments and suggestions, and to Osman Sari, assisted by Nisangul Ceran and Zhang Zhu, for price collection and statistical work on the recent data and to James Hayes and Rosa Schupbach for the preparation of the manuscript, An earlier version of the paper was presented at the Conference on International Economic Transactions of the NBER Conference on Research in Income and Wealth, in Washington, D.C., Nov. 3 and 4, 1989.
} 
The list of defects is a long one. For many countries, no price data are collected for exports and imports, and many studies of trade rely on indexes of export and import unit values, despite a long history of adverse appraisals of their accuracy, particularly for manufactured goods. 1 Not only are the unit values inaccurate as measures of the prices of individual products, but in each country they are combined with different weights, and using different index number formulas.

In the case of primary goods, quality changes were thought to be relatively small, and where they were not, prices based on narrow specifications were often available as a check on the data based on unit values. The introduction of new products was not thought to be a major problem. While there have been many large shifts in sources of supply for primary products, most scholars have been willing to accept that, for these goods at least, the law of one price worked well enough that a missing price observation could be safely filled in using the price of the same product from another country. None of these reassurances can be applied to the prices of manufactured goods. It is possible that there is serious underrepresentation of new commodities, at least for part of their history. There have been suggestions that price indexes for manufactured goods suffered from upward bias due to the neglect of quality châninge. Export prices for automobiles, for example, might not take into account gains in horsepower, the shift to power brakes and steering, anti-pollution devices, etc. More important, perhaps, is the omission of many products from most countries' price indexes. Computers and computer accessories may be excluded completely, although they have become a major part of manufactured goods trade. The fact that manufactured products from different countries are less substitutable for each other than primary 
products from different sources means that the omission of one country's prices for some manufactured products is much more likely to bias an index than the omission of one country's primary product prices.

An alternative to the unit value indexes is the use of wholesale or producer price indexes. These are collected with a much higher degree of quality control than is applied to the unit value indexes, at least in some countries. However, the prices do not purport to apply to external trade. The difference in movement between domestic and export prices can be significant, as is pointed out in the sources mentioned above and in Kalter (1978), Kravis and Lipsey (1977a and 1977b), where these differences are interpreted as reflecting changes in export profit margins, Baldwin (1988), Dornbusch (1987), Krugman (1987), Mann (1986), Marston (1989), and Ohno (1989). ${ }^{2}$ The producer price indexes share the characteristic of the unit value indexes that they are computed with different weighting, coverage, and index number formulas in different countries. For both types of indexes, the fact that the methods of computation differ greatly from one country to another stems from the fact that they are computed by national statistical agencies for their own purposes, for which they may be quite satisfactory.

A further consequence of the dependence on price collection by individual countries is that it builds in an assumption about price behavior. The assumption is that prices of goods not covered by a country's price collection process move identically with prices of covered commodities in the same general class or, if the whole class is uncovered, with the prices of commodities in general. It is implicitly assumed that price movements of the same product in other countries convey no information at all about the likely change in the missing prices. That is an odd choice of assumptions for a 
profession that often assumes the operation of purchasing power parity or the "law of one price." The practical implication can be imagined in the case of a comparison between a country that covers computer prices in its price index and a country that omits them and assumes they follow prices of other products.

In this paper, we construct a set of international price indexes for manufactured goods for 1953 to 1988, that addresses these issues in several ways. 1. Weighting. We construct two types of indexes of manufactured goods prices. One is intended mainly for studies of competition in international trade. It is calculated for the United States and for the aggregate of many of its major competitors, using the export weights of the United States and weighting at a fine level of commodity detail such as the 4-digit SITC. A similar calculation is performed for Germany and its competitors, using German export weights, and for Japan and its competitors, using Japanese export weights. Index of domestic prices with own-country export weights are also calculated for each of the three countries to examine the possibility of divergences between export and domestic price movements and their implications for changing margins of profitability of export and domestic sates.

A second type of index, used, for example, in studying world trends in terms of trade, is a "world" index of manufactured goods prices, using as weights aggregate OECD exports or developed country exports to developing countries. We also construct indexes for individual countries based on these two sets of weights.

For all of these types of indexes, we carry out the calculations using weights from a relatively early date, 1963, and from a later date, 1975. 
2. Missing prices. In place of the assumption that prices for products not covered move in the same way as those covered in the same country, we use, in the aggregate indexes for all developed countries, a method that incorporates both country and commodity effects in estimating missing prices. The method is an adaptation of one developed by Summers (1973) for the estimation of country price levels. It involves fitting an equation to each block of country and commodity price change observations for a given year. The block is defined by the full list of commodities and countries in, say, a two-digit SITC class. The equation contains dummy variables for both country and commodity and therefore permits the data to determine the degree to which each influences the estimate of the missing price. The list of variables could be expanded to include, for example, a dummy variable for the use of a hedonic price index or a variable to represent the movement of the price in the preceding year.

3. Quality corrections. One reason for doubts as to the accuracy of price indexes for manufactured products is the suspicion that they do not take adequate account of changes in the quality of these goods and are biased upward on that account. There have been no studies that examine changes in quality specific to exports and imports but a fair number of studies of quality change, and of the correction of prices for quality change, by the use of hedonic price measures. We show the effect on the U.S. expor.t price indexes of introducing the quality-adjusted price measures that have been calculated for a few commodities in the United States. We then also show the effect on world price indexes of introducing these quality adjustments, under several possible assumptions about the relation between quality change in the U.S. and quality change in other countries. 


\section{METHODS AND SOURCES}

\section{Sources of Detailed Price Data}

The indexes are based on disaggregated export price data for countries for which they are available, with gaps filled by producers and wholesale price indexes and hedonic price indexes, where possible.

There are severat basic ingredients for our indexes. The first are the international price indexes for metals, metal products, machinery, and transport equipment, for the United States, the United Kingdom, Germany, and Japan, covering 1953-1964 from Kravis and Lipsey (1971), with interpolations based on the other types of data, as explained for the case of Germany in Kravis and Lipsey (1972). The second are the official export price indexes produced by the U.S., Germany, and Japan, the latter two fairly comprehensive, the first starting with the same coverage as the Kravis-Lipsey indexes and gradualiy increasing in coverage over time until they are now quite complete. The third element of our indexes is more fragmentary export price data published by the U.K., Sweden, and the Netherlands, the last gradually increasing in scope over the years. The fourth type of data is producer price indexes and/or wholesale price indexes for all the countries mentioned above and also for France and Canada. The fifth type is hedonic price indexes for a few types of machinery and transport equipment in the United States. These are used in two ways. The first is to fill in prices for some commodities for which no official published indexes exist. The second is as a substitute for conventional price series in a very rough attempt at adjustment for quality change, where we consider it appropriate and important.

The various sources of data, of course, overlap extensively in commodity coverage. It is therefore necessary to assign price series to the index by 
systems of priorities, determined by our view as to the appropriateness of each type of data as measures of export prices. In the world price series or those for developed country exports to developing countries, the highest priority is given to series representing prices in international trade, first the Kravis-Lipsey series and then official export price series. The second priority is for producer or wholesale prices, and the third for the hedonic price indexes. Although we consider the hedonic price series more appropriate for our purposes than the conventional series, we have not given them priority because we wished to produce indexes from something close to conventional data. However, we have also calculated an alternative index in which hedonic price series are given priority, and we consider that to be the best estimate we can make of the movement of prices of manufactured goods.

In the export price indexes based on each country's own export weights, only export prices themselves are used in each own-country index. The indexes for competing countries give export prices the first priority, and producer or wholesale prices the second, but no hedonic price indexes are used because the hedonic price data are confined to the U.S. The results would depend too heavily on whether hedonic indexes were applied only to the U.S. or are assumed to reflect similar changes in quality in other countries' exports.

The domestic price indexes based on export weights use no export prices and are based entirely on producer or wholesale prices.

The precise sources of the price data are given in Appendix A.

\section{Weighting Schemes and Missing Price Observations}

As was suggested in an earlier paper (Kravis and Lipsey, 1984), the selection of systems of weighting is second only to the selection of basic price data in determining the characteristics of the resulting price indexes. 
Severai different methods have been used, impiying different assumptions not oniy about the importance to be given to commodities but also, usually inadvertently, about the behavior of prices for which data are unavailable.

We can think of a set of worldwide weights representing the values of exports of each commodity (defined here as a four-digit SITC subgroup) from each country $\left(\omega_{i j}\right)$, to be used in weighting price relatives showing changes over time in individual prices $\left(P_{i j}\right)$.

If we think of the weights in the form of a country by commodity matrix, we have:

\begin{tabular}{|c|c|c|c|c|c|}
\hline \multirow[b]{2}{*}{ Commodity } & \multicolumn{4}{|c|}{ Country } & Countr \\
\hline & 1 & 2 & 3 & $\ldots \ldots \ldots m$ & \\
\hline 1 & $\omega_{11}$ & $\omega_{12}$ & $\omega_{13}$ & $\ldots \ldots \omega_{1 m}$ & $\omega_{1 T}$ \\
\hline 2 & $\omega_{21}$ & $\omega_{22}$ & $\omega_{23}$ & $\ldots \ldots \omega_{2 m}$ & $\omega$ \\
\hline 3 & $\omega_{31}$ & $\omega_{32}$ & $\omega_{33}$ & $\ldots \ldots \omega_{3 m}$ & $\omega_{3 T}$ \\
\hline - & $\cdot$ & $\cdot$ & . & $\ldots \ldots$. & \\
\hline • & $\cdot$ & $\cdot$ & $\cdot$ & $\ldots \ldots$ & \\
\hline$n$ & $\omega_{n 1}$ & $\omega_{n 2}$ & $\omega_{n 3}$ & $\ldots \ldots \omega_{n m}$ & $\omega_{1}$ \\
\hline$\Sigma$ Commodities & $\omega_{T 1}$ & $\omega_{\top 2}$ & $\omega_{\top 3}$ & $\ldots \ldots \omega_{T m}$ & $\omega$ \\
\hline
\end{tabular}

The most common method for constructing price indexes for aggregates of countries, such as those used in models that cali for "worid" or "rest-ofworld" prices of export goods or traded goods, is to use the pubiished 
country aggregate price indexes and to weight them together by some set of weights representing the importance of each country in world trade. The importance of each country might be measured by the value of trade or, in some cases, by weights derived from a model. In terms of the matrix above, these aggregate indexes are of the type:

$$
P=\sum_{j=1}^{m} \omega_{T j} \sum_{i=1}^{n} \omega_{i j} P_{i j}
$$

It is usually uncertain in these calculations, since they do not go behind published aggregates, what commodities are included with what commodity weights, and with what base years. It is likely that many of the country indexes lack proper representation of complex manufactured products. Given all these characteristics, it is not surprising if elasticities of substitution or price elasticities of demand are found to be low or if no significant relationships can be found.

In an effort to overcome some of these problems, we have, at times, calculated indexes for various countries in which the same set of commodity weights at the four-digit SITC level was applied to each country's prices.4 The differences between one country's aggregate price change and those of rivat countries were then more clearly attributable to differences in price changes for the same products rather than to some mixture of these with differences in the coverage or weighting of products. In terms of the matrix above, these price indexes were of the form

$$
P=\sum_{j=1}^{m} \omega_{T j} \sum_{i=1}^{n} \omega_{i T} P_{i j}
$$


Both of these types of indexes involve the same assumptions about the nature of the commodities priced at the most detailed level and about price relationships, since each involves filling in missing price observations using only data for the same country. The justification for starting with the calculation of country indexes is the assumption that missing prices tend to behave in a similar manner to the average of other prices in the same country for commodities in the same 3-digit, 2-digit, or 1-digit commodity classes. These methods, therefore, ignore the behavior of other countries' prices for the same commodity, a difficult assumption to accept for anyone who believes price movements in different countries are correlated at all.

An alternative method of calculating world or other price indexes aggregated over countries would be

$$
P=\sum_{i=1}^{n} \omega_{i T} \sum_{j=1}^{m} \omega_{i j} P_{i j}
$$

in which a world price index for each commodity would be calculated first, and $a 11$ these would then be aggregated across commodities using worldwide commodity trade weights. This procedure would come closer to acceptance of the law of one price than those outlined above, since it assumes that one country's price for a commodity tends to move with the average of other countries' prices for the same commodity. However, it therefore assumes that there is no country-specific effect on a price change. Thus, a curreney revaluation is presumed to have no effect on the export price of the revaluing country in comparison to that of others, a proposition we have found in our studies of international price behavior to be contradicted frequently. 5 A preliminary test of the two extreme assumptions, reported in Kravis and 
Lipsey (1984), was to compare the variance of price movements among countries at the 1-digit SITC level with the variance among 4-digit commodities within 1-digit commodity divisions within countries, using year-to-year price movements for the U.S., Germany, and Japan. The variance among countries within 1-digit classes was 7 arger than the variance among 4-digit commodities within a class within countries. The conclusion there was that "... if either country alone or commodity alone had to be used as the criterion for assigning missing price observations, country would be a better choice." However, considerable further tests would be needed to make a definitive judgment on this issue. Estimating Missing Prices by the Country-Product Dummy Method

Despite the range of sources from which we collected price data, it was not possible to collect prices for every item for every country for every year. The earlier studies by Kravis and Lipsey adopted the almost universal procedure of setting some minimum level of coverage for a group of commodities and, if that level was achieved, using the average price change for covered commodities as an estimate of that for the whole group, assuming in effect that the prices of uncovered items move, on average, identically to those of covered items. We continue to use this method for the individual country price indexes based on own-country weights (Appendix $\mathrm{C}$ ).

Common though this procedure for estimating missing prices is, it discards some probably pertinent information about the missing category: the price change for the corresponding product in other countries. We have therefore used a different method for the developed country price indexes. This method, referred to as the country-product dummy (CPD) method, was developed by Robert Summers (1973) for use in estimating missing price levels for inter-country price comparisons in the United Nations International Comparison Project 
(ICP). Its purpose was to use information on both country influences and product influences on the price of a product to estimate each missing price. In its original version, discussed by Summers, it involved regressions for commodity groups using natural logs of the price levels as the dependent variable, and country and product dummies as the independent variables. There was a product dummy variable for every product in the group, and a country dummy variable for every country but one, which was designated the base country. The coefficient of a country dummy term for country $j$ in one of these equations represents the natural $\log$ of the ratio of the price level in this commodity group in country $j$ to the price level in the base country. If we translate the equation into naturai numbers, the price level for country $j$ appears as an exponent in the equation.

We wished to estimate not only commodity group price changes but also the price changes for each missing item. We created as dense a price matrix as possible at the 4-digit leve 1 as a first step, thereby permitting weighting and reweighting as our needs changed. We estimate the missing prices by using the commodity dummy coefficients in conjunction with the country dummy coefficients. Because there is no dummy for the base country, the commodity dummy coefficients are estimates of the prices for those commodities in the base country. To estimate a price missing in the base country's data therefore, we used the exponent of the appropriate commodity dummy. For any other country, we multiplied the exponent of the coefficient for the product by that for the country: we adjusted the "base" price for a commodity for the group price difference between the base country and the dummy country.

In running the regressions, we had two procedural problems to resolve. The first was to define the commodity groups within which we would run 
regressions. A group should be defined narrowly to make it as homogeneous as possible while still retaining sufficient degrees of freedom for a regression. The 2-digit SITC categories were the starting points, but some groups had too few SITC subdivisions and others had too few available observations. Therefore, in cases where the regression for a 2-digit group would have had less than 10 degrees of freedom, we pooled it with other small 2-digit groups in the same 1-digit division. The second problem was that data were so scarce for certain countries in various years and groups that we felt that the estimates for these countries would be statistically meaningless. Therefore, in any one regression, we included only countries for which we had price data for 3 or more commodities within the group, as we 11 as those for which even a smaller number of items accounted for $30 \%$ of the group weight. The weights for commodities and groups were based on 1963 OECD exports. These procedures were applied on a yearly basis, so that while two groups may have been combined in an early year because neither one included a sufficient number of observations, they may have been treated separately in a later year if the number of available prices increased. Similarly, a country excluded in one year might be included in another if the coverage of its price data improved.

\section{Aggregation of Detailed Price Indexes}

Once we had run regressions for every 2-digit group and year for which it was feasible, and the resulting price estimates were used to fill in any holes at the 4-digit leve1, the 4-digit price indexes were weighted up to the 3-digit leve1. Not every 3 -digit group price index could be estimated by aggregation. If the price index for a 3-digit group was "missing" because there were not enough data at the 4-digit leve1, the index at the 3-digit level was estimated by the same regression procedure, where possible. After 
the 3-digit estimates were added, and the data were weighted up to the 2-digit leve1, regressions were run to estimate any missing 2-digit groups. In both cases, the weights used were 1963 OECD exports to the world.

After filling in as much data as needed, we created a master price file for each country that contained all the necessary data at every level. These are the files we used, weighted together using various weights, to create the various price indexes for total developed country exports and developedcountry exports to developing countries reported here.

\section{INDEXES OF "WORLD" EXPORT PRICES FOR MANUFACTURES}

\section{Weighting and Country Coverage}

We have calculated two aggregate price indexes for exports of manufactured goods by developed countries, differing in their weighting but not in the price series used. One is an index weighted by the value of all exports of manufactures by developed countries, including their exports to each other. The other is an index weighted by the value of exports by developed countries to developing countries. The former is relevant to issues such as the terms of trade between manufactures and primary products, and the latter is more relevant to discussions of the terms of trade between developed and developing countries.

Both of these indexes were constructed with two sets of weights: 1963 exports by all OECD countries and 1975 exports by the same countries. The developed market economies, a class almost equivalent to the OECD, accounted for 82 per cent of the world's exports of manufactures in 1965, 84 per cent in 1975, and 78 per cent in 1985. Of the exports by developed market economies, those countries covered by our indexes (although not necessarily covered for 
all commodities) accounted for 77 per cent or, in other words, about 60 per cent of wor 1d exports of manufactures. 6

\section{Effects of Differences in Time Period Used for Weighting}

Two time periods, 1963 and 1975, have been used to weight the price indexes for all developed-country exports and exports from developed countries to developing countries. If we compared the price movements between 1963 and 1975 derived from the two measures, it would be equivalent to the familiar comparison of Laspeyres and Paasche price indexes, with the index on the 1963 weight base the Laspeyres price index (or the one based on earlier weights) and the index on the 1975 weight base the Paasche price index. An increase in the 1963-based index relative to the 1975-based index would imply a negative covariance between prices and quantities, while a relative increase in the 1975-based index would imply a positive covariance. We could associate the negative covariance with a situation in which events were dominated by changes in supply, with demand relatively stable. The positive covariance implies a situation dominated by changes in demand, with supply relatively stable.7 The differences in the trend of prices produced by the shift in weight base from 1963 to 1975 were as follows: 
Export Price Index for All Manufactures, 1988 $(1953=100)$

OECD Export Weights of

$\begin{array}{lllc} & 1963 & 1975 & 1963 / 1975 \\ \text { A11 Developed Countries } & 444.8 & 423.3 & 105.1 \\ \text { U.S. } & 383.5 & 373.0 & 102.8 \\ \text { Germany } & 573.8 & 558.0 & 102.8 \\ \text { Japan } & 372.0 & 354.7 & 104.9\end{array}$

Source: Appendix Tables B1, B2, B5, B6, B9, B10, B13, B14.

In every case, the index with a later weight base rose less than the one with an earlier base, implying the dominance of changes in supply and substitution in favor of products for which price increases were relatively small. The difference was larger in the index for all countries than in any of those for individual countries. That fact implies that in addition to substitution among commodities, there was also substitution among countries in favor of those with relatively declining prices, presumably those in which productivity and export supply were increasing most rapidly.

Despite the fact that there were wide divergences among the countries in the size of the increase in prices over the period as a whole, the effects on the price indexes of changing weights were fairly small, ranging only from 3 per cent for the US and Germany to 5 per cent for Japan. That narrow range reflects the fact that the same weights are used for all the countries' indexes. In the case of the export price indexes based on own-country weights, shown in Appendix $C$, the differences are considerably larger, ranging from 3 per cent for Germany to 9 per cent for Japan and the U.S. All the indexes 
show a larger price increase for the series using the earlier weight base, implying dominance by supply changes and substitution toward products falling in price, and there was apparently more substitution, or a wider range of price changes, within U.S. and Japanese exports than within German exports or those of all developed countries as a group.

The relationship between indexes based on the two sets of weights varied somewhat among commodity divisions. In most cases, the later weight base was associated with a smaller price increase, but there were some exceptions, as can be seen below:

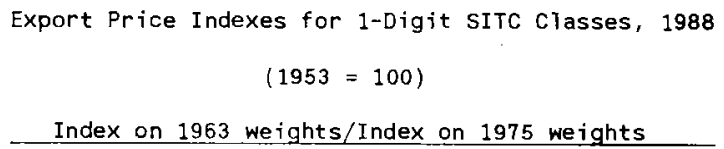

\begin{tabular}{llll} 
SITC & \\
\hline 5 & 6 & 7 & 8
\end{tabular}

$\begin{array}{lcccc}\text { A11 Countries } & 1.056 & .990 & 1.113 & 1.018 \\ \text { U.S. } & 1.075 & .979 & 1.035 & 1.042 \\ \text { Germany } & 1.075 & 1.003 & 1.044 & 1.049 \\ \text { Japan } & 1.046 & 1.031 & 1.023 & 1.041\end{array}$

Source: Appendix Tables B1, B2, B5, B6, B9, B10, B13, B14

The cases in which the earlier set of weights led to lower price index changes were in SITC 6, which consists mainly of semimanufactures. In that group, for the United States, changes in prices and in quantities were positively correlated, implying the likelihood that the price changes were dominated by changes on the demand side rather than the supply side. 
Export Prices to the world and to Developing Countries

Since the composition of exports to developing countries might be different from that of exports to other countries, it is conceivable that they faced larger or smaller price increases than other buyers. That possibility is examined below for manufactured goods as a whole and the four major categories of manufactures.

$\begin{array}{ccc}\text { Export Price Index, } & 1988(1953=100) \\ \frac{1963 \text { Weights }}{\text { Exports to }} & \frac{\text { Exports to }}{\text { Developing }} & \text { A11 Developing } \\ \text { Countries Countries } & \text { Countries Countries }\end{array}$

$\begin{array}{lcccr}\text { A11 Manufactures } & 445 & 423 & 423 & 403 \\ \text { SITC 5 } & 363 & 365 & 344 & 341 \\ \text { SITC 6 } & 432 & 413 & 437 & 418 \\ \text { SITC 7 } & 476 & 456 & 428 & 425 \\ \text { SITC 8 } & 438 & 392 & 430 & 384\end{array}$

Source: Appendix Tables B1 through B4

In most cases, exports to the world (and therefore exports to the developed world to a greater degree) increased more rapidly in price over the three and a half decades than exports to developing countries. That was the case for manufactured products as a whole, and for SITC divisions 6, 7, and 8. The largest differences, over 10 per cent, were in SITC 8 , a category in which the developing countries were themselves substantial exporters. 
An earlier version of the price indexes for exports to developing countries was compared, in Kravis and Lipsey (1984), to the UN unit value index for manufactures that is customarily used for calculations of manufactured goods prices and terms of trade. The conclusion was that prices of manufactured goods exported by developed countries to developing countries had risen much less than had been suggested by the unit value indexes: something in the neighborhood of 75 per cent over the period from 1953 to 1976 , as compared with 140 per cent for the unit value index. About a half of the difference stemmed from the corrections for quality change and the other half from some mixture of differences in the type of price data used (prices vs. unit values), in index number formulas, and in country coverage. The different price measure for manufactured goods also implied, of course, a larger decline in the terms of trade of manufactured goods relative to primary products than had been shown by the unit value indexes.

\section{Adjustments for Quality Change}

The proper treatment in a price index of changes in the quality of goods has been a controversial issue for many years. A considerable amount of work has been done, particularly by the application of hedonic methods, to adjust domestic price indexes for changes in quality that are supposedly not adequately accounted for, even in price indexes gathered with considerable attention to quality specifications. Most of this research has been directed to consumer and producer capital goods, almost all of which are included in SITC 7 of our product range.

Almost no empirical attention has been given to the same issue in connection with prices in international trade, although speculations on the effects 
of omitting quality change have played a role in discussions of the long-run trends in the terms of trade (Haberler, 1959; Viner, 1953, p. 114). The only direct applịcations of hedonic methods to international trade prices that we are aware of, mainly for deriving price level comparisons, were in Kravis and Lipsey (1971). In a study of the terms of trade between manufactures and primary products, Kravis and Lipsey (1984) used hedonic indexes constructed for domestic prices to adjust indexes of export prices of manufactured goods, and we follow similar procedures here.

There are many possible ways of using these domestic price adjustments for quality to correct international price indexes. Since these calculations have been performed only for domestic prices, it is necessary to assume that any adjustments in domestic prices were equally applicable to U.S. export prices. The hedonic price indexes are available only for the United States, and for only a few commodity groups even for the U.S. Therefore, the adjustments we make in the U.S. indexes are probably minimal, and those for the world can be considered to be no more than rough approximations that give some notion of the direction and range of conceivable quality corrections.

One possibility would be to assume that the adjustments apply only to the U.S. If the quality adjusted U.S. indexes are combined with conventional indexes for other countries, the result is a very conservative estimate of the effect of such adjustments on world or developed country export price movements. That estimate of the quality change omitted from conventional measures, provided by the series described below as "adjusted for U.S. on 7y," is conservative in several respects. One is that it assumes that the upward bias in price indexes from this source affects only the U.S. data, an unlikely possibility. Another is that most of the hedonic price indexes end with 1983 , and 
no adjustment can be made for later years in even those groups for which it was performed earlier. A third reason is that a number of price indexes that should be corrected for quality change were not, because appropriate indexes were not available.

The procedure of correcting only U.S. prices is likely to leave an upward bias in a world price index. Ideally, we would like to have similar hedonic price measures for all countries, but failing that, we believe it is more appropriate to assume that any quality adjustment applied to, for example, U.S. computer and parts prices, is equally applicable to the corresponding prices of other countries than to assume that the unmeasured quality change is confined to the U.S. Also, on this assumption, if an otherwise empty cell for computer prices is filled in one country by a hedonic price index, it should be filled in the other countries by the same type of index. The assumption implied by that procedure is that the law of one price in time-to-time form, poor as we have found its predictions to be (Kravis and Lipsey, 1978), still provides a better guess for these products than the assumption that, for example, computer prices in countries other than the U.S. move with all other prices in those countries. The indexes based on the assumption of identical price movements in all countries for products for which hedonic price indexes were used are described below as "adjusted for all countries."

This procedure of assuming identical price changes for a product in different countries is at variance with the method implied by our earlier conclusion that country influences, rather than commodity influences, were dominant in determining price changes. However, that conclusion reflected mainly the impact of exchange rate changes and differences in inflation rates on price movements. The application of identical quality adjustments to a commodity in 
different countries reflects our judgment that radical changes in technology in an industry such as computers, for example, probably outweigh the country influences on price changes. That judgment is influenced partiy by the fact that a substantial part of exports of machinery from countries outside the U.S., especially in the computer industry, originates in subsidiaries of U.S. firms, and therefore embodies U.S. technological developments.

The effect of the quality adjustment applied to a few groups in SITC 7, Machinery and Transport Equipment, can be seen from the following comparison: Ratio of 1988 to 1953 World Export Price of Manufactures, With and Without Quality Ad justments: 1975 Weights

\section{A11 Manufactures}

OECD Export Weights

$\begin{array}{ll}\text { Unadjusted } & 423.3 \\ \text { Adjusted for U.S. only } & 406.7 \\ \text { Adjusted for all countries } & 361.1\end{array}$

SITC 7

OECD Export Weights

$\begin{array}{ll}\text { Unadjusted } & 427.7 \\ \text { Adjusted for U.S. only } & 389.0 \\ \text { Adjusted for all countries } & 310.9\end{array}$

Source: Appendix Tables B2 and B19

If the adjustment is performed only for the U.S., the effect on the world export price index for manufactures is fairly small: only about .15 per cent 
per year for manufactures as a whole and about .25 per cent per year for SITC 7. If the corresponding quality adjustments are spread to other countries, the effect is multiplied. For manufactures as, a whole, it is almost a half of one per cent per year, and for SITC 7 it reaches almost one per cent per year.

The quality adjustments for manufactures as a whole would be larger for an index based on U.S., or especially Japanese, export weights because SITC 7 is more important in the exports of those countries than in those of developed countries as a group.

These adjustments are too gradual and not large enough to produce a different picture from the standard one of short-term fluctuations in the terms of trade between manufactures and primary products, or the terms of trade of individual countries. They are large enough, and sufficiently constant in direction, to give a very different story about long-term trends in prices and terms of trade.

\section{INDEXES OF EXPORT PRICES, EXPORT PRICE COMPETITIVENESS,} AND CORRESPONDING DOMESTIC PRICES

The price indexes in Appendix B for all developed country exports of manufactures and for exports by developed countries to developing countries are constructed from indexes for individual countries that are all based on the same set of weights. However, these are weights that reflect the importance of products in world trade as a whole rather than in the trade of each country. To explain the exports of a single country, such as the U.S., we consider an index based on that country's export weights more relevant. For this purpose, we have constructed price indexes for each country's exports that are based on the weight of each product in the country's exports. We have then 
constructed price indexes for competitors based on the same set of weights. Thus, for the U.S., we have an export price index and a competitors' price index, both based on U.S. export weights. All of these are shown in Appendix $\mathrm{C}$.

For the individual country, the price index is a conventional export price measure, but unlike the indexes in Appendix $B$, which use domestic prices where export prices are unavailable, these include only export price data. The index of competitors' prices is, in the case of the U.S., weighted by the same U.S. export weights as the U.S. export price but includes both export price data and, where they are not available, domestic price data, as in the indexes of Appendix B. That procedure produces manufactured goods price indexes for Germany, Japan, and other countries with U,S. export weights. To explain the exports of the U.S. itself, or its share vis-à-vis the rest of the world, we combine these competitors' price indexes on U.S. weights into a single restof-world price index. The weight for a competitor country in this index is the sum. of the total manufactured exports of the country to destinations other than the U.S., to represent the competition in world markets outside the competitor country and the U.S., and total U.S. exports to the competitor country, to represent competition with U.S. exports in that country's home market.

The same procedure is followed to produce individual country and rest-ofworld indexes for the exports of Germany and Japan.

One way to use these indexes is to ask what they show about the export price movements for each country relative to those of competitors. For example, if we separate the period into that preceding the Smithsonian agreements of 1971 and that from 1971 to the low point in the exchange value 
of the U.S. dollar in 1980, we find the following estimates of changes in prices and relative prices.

\begin{tabular}{|c|c|c|c|c|c|c|}
\hline & Changes & $\begin{array}{l}\text { in Own and } \\
1953 \text { to }\end{array}$ & $\begin{array}{l}\text { Compet } \\
1971 \text { an } \\
\text { Ratio }\end{array}$ & $\begin{array}{l}r s^{\prime} \text { Exp } \\
971 \text { to } \\
00)\end{array}$ & $\begin{array}{l}\text { ort Price } \\
1980\end{array}$ & Index \\
\hline & & $1971 / 1953$ & & & $1980 / 197$ & \\
\hline & U.S. & Germany ${ }^{a}$ & Japan & U.S. & Germany & Japan \\
\hline Export Price Index & 146.5 & 147.9 & 93.0 & 176.4 & 306.2 & 231.1 \\
\hline Competitors' Price Index & 123.7 & 118.5 & 123.9 & 272.9 & 249.6 & 252.6 \\
\hline Ratio: Own/Competitors & 118.4 & 124.8 & 75.1 & 64.6 & 122.7 & 91.5 \\
\hline
\end{tabular}

$a_{1971 / 1954}$

Source: Appendix Tables $\mathrm{C4}$ through $\mathrm{C6}$

Both the U.S. and German export prices rose from 1953 to 1971 relative to those of other countries that sold the same export products. Japanese prices fell enormously relative to those of its competitors during the same period, with a decline of 25 per cent in relative prices. From 1971 to 1980 , the U.S. gained greatly on its competitors, with a fall of more than a third in relative prices. Japanese relative prices also fell during this period, although not as much as those of the U.S., while German relative prices continued to increase.

The corresponding changes for the period of the rapidly rising exchange value of the dollar, which we can mark out as 1980 to 1985 in these annual average data, and the subsequent period of the declining dollar, are shown below: 
Changes in Own and Competitors' Export Price Indexes, 1980 to 1985 and 1985 to 1988

(Ratio $\times 100)$

\begin{tabular}{|c|c|c|c|c|c|c|}
\hline & \multicolumn{3}{|c|}{$1985 / 1980$} & \multicolumn{3}{|c|}{$1988 / 1985$} \\
\hline & U.S. & Germaniy & Japan & U.S. & Germany & Japan \\
\hline Export Price Index & 125.5 & 74.2 & 94.9 & 110.1 & 172.3 & 150.2 \\
\hline Competitors' Price Index & 82.1 & 94.6 & 87.8 & 160.5 & 140.3 & 146.6 \\
\hline Ratio: Own/Competitors & 152.9 & 78.4 & 108.1 & 68.6 & 122.8 & 102.5 \\
\hline
\end{tabular}

Source: Appendix Tables $C 4$ through C6

The indexes show a large increase in relative U.S. prices during the rise of the dollar and a sharp decrease during the next three years, with the net result being some increase over the eight years. The movements for Germany were the reverse of those for the U.S., but involved a small overall decrease in relative prices. The changes for Japan were a relative price increase in 1980 to 1985 , despite the rise in value of the sus, and an additional increase after that, quite small considering the sharp increase in the exchange value of the yen.

Perhaps the most surprising feature of these price measures is the apparent relative increase in German prices after 1985 without a corresponding reflection in German export shares. One possible reason for this seeming lack of response to price changes is that.German exports gained from the growth and enlargement of the EEC. Another is that the omission of Italian and Belgian prices from our measures, along with poor coverage of French prices, particularly of machinery in the earlier years, may have caused these indexes for 
German competitors' prices to be biased upwards.

These relative price indexes are similar to those we have referred to elsewhere as indexes of price competitiveness (Kravis and Lipsey, 1971), although the price competitiveness measures were based on OECD weights for the individual countries, as are those for individual countries in Appendix $B$ of this paper. The relation between these measures and broader concepts of competitiveness, including "nonprice" aspects, was discussed in the earlier work. The "price competitiveness" measures were not intended to encompass a 11 the economic influences on that broader concept, although the price measures must reflect some of the broad movements in relative productivity and costs that are part of changes in a country's competitiveness. We think of relative price changes, as we have measured them, as useful for reduced form trade equations. In more structural trade models, the export price changes become endogenous variables in supply equations. ${ }^{8}$

Even if these indexes have a more logical basis than the ones usually used to analyze trade, an obvious question is whether they produce any more reliable estimates of elasticities or better explanations of the flow of trade. An authoritative answer to that question could on ly come from attempts to use these measures in various types of trade equations and models of trade. We can report on a few experiments along these lines with earlier versions of the indexes.

In one of these experiments (Kravis and Lipsey, 1974), we estimated elasticities of substitution between U.S. and German exports of metals, machinery, and transport equipment to third-country markets using, as alternative price measures, indexes of the type constructed here from export price data and indexes based entirely on domestic prices. We considered the test to be 
more favorable to the domestic price indexes than a comparison based on the usuat published indexes because we reweighted the domestic prices by international trade weights to match the export price indexes.

The results of the comparison were that the degree of explanation was between twice and three times as great in equations using the export price indexes, and the elasticity estimates were much higher. Furthermore, the response of relative exports was almost the same for a change in U.S. prices as for a change in German prices, while in the equation based on domestic prices, the elasticities were quite different.

A later version of these indexes covering machinery and transport equipment was used in Bushe, Kravis, and Lipsey (1986) to explain changes in U.S., German, and Japanese exports. It is difficult to compare the results with those of other studies because of differences in commodity coverage and time periods, but one conclusion was that the differences among countries in price elasticities were smaller than had been estimated using other price data. However, we could not be sure whether our use of more accurate price data or our confining the comparison to the same range of commodities was the explanation for the greater similarity of elasticity coefficients. Another conclusion was that lags in price effects on U.S. exports were much longer, extending out to 4 years, than those in most previously estimated export equations, and that "... the United States might have to wait a long time for any relief from the effects of the high value of the dollar in the mid-1980s."

\section{Margins on Export and Domestic Sales}

We have also calculated (Appendix C) domestic price indexes for exported manufactured goods for the U.S., Germany, and Japan, using each country's export price weights. These data can be used to examine changes in the ratio of 
export to domestic prices for each country. If costs for domestically sold and exported goods changed identicaliy, that ratio reflects the direction of change in gross profit margins in export as compared with domestic sales and a)so, if domestic price movements are a good proxy for cost changes, the direction of change in export margins themselves. With the extreme volatility of exchange rates that has characterized the $1980 \mathrm{~s}$, and the observation that prices of Japanese goods in the United States have not risen in line with the depreciation of the dollar since 1985, there has been a renewal of interest in this issue with several studies of changes in the export/domestic price margin or "pricing to market" (Krugman, 1987; Marston, 1989; Mann, 1986). However, as noted below, the phenomenon of pricing to market was evident to some degree in earlier periods, although not as dramatically as in the years since 1985 .

On the whole, we would expect relative declines in export margins in periods when the exchange value of the currency is increasing or, more generaliy, when domestic prices are rising more rapidly than those of competitors. We would expect rising margins in periods of falling currency values or falling relative domestic prices.

The results for the U.S. from 1953 to 1980 do not give much support to these expectations. U.S. export prices hardly changed relative to domestic prices from 1953 to 1971 when U.S. prices were rising relatively, and they declined relative to export prices in 1971 to 1980 as U.S. prices fell-with the depreciation of the dollar. 
Changes in Export and Domestic Prices of Export Goods, 1953 to 1971 and 1971 to 1980

\begin{tabular}{|c|c|c|c|c|c|c|}
\hline & \multicolumn{6}{|c|}{ (Ratio $\times 100)$} \\
\hline & \multicolumn{3}{|c|}{$1971 / 1953$} & \multicolumn{3}{|c|}{$1980 / 1971$} \\
\hline & U.S. & Germany & Japan & U.S. & Germany & Japan \\
\hline Export Price Index & 146.5 & 147.9 & 93.0 & 176.4 & 306.2 & 231.1 \\
\hline Domestic Price Index & 145.8 & 165.0 & 88.2 & 210.9 & 306.3 & 243.0 \\
\hline Ratio: Export/Domestic & 100.5 & 89.6 & 105.4 & 83.6 & 100.0 & 95.1 \\
\hline
\end{tabular}

Source: Appendix Tables C4 through C6

The export/domestic price ratios for Germany and Japan did move in the expected direction during the period of mostly fixed exchange rates from 1953 to 1971 . In the first period of changing exchange rates, 1971 to 1980 , the German ratio was stable even as German relative prices increased, and the Japanese ratio fell even while Japanese prices were declining relative to those of competitors. That was a period in which Japan was under great pressure to expand exports to offset the rise in petroleum import costs.

The 1980 to 1985 period of great exchange rate turbulence and rising exchange value of the dollar saw somewhat surprising changes in export/domestic price ratios. U.S. export prices rose relative to domestic prices despite a large increase in U.S. export prices relative to competitors. German export prices fell relative to donestic prices, although German export prices were falling relative to those of other countries. And Japanese export prices hardly changed in comparison to domestic prices while they were rising relative to foreign countries' prices. 
The dollar depreciation in the following period was accompanied by a rise, as expected, in the export/domestic price ratio in the U.S., but it was a small one. There were also the expected declines in export/domestic price ratios in both Germany and Japan, the former quite smal1.

Changes in Export and Domestic Prices of Export Goods, 1980 to 1985 and 1985 to 1988

\begin{tabular}{|c|c|c|c|c|c|}
\hline \multicolumn{3}{|c|}{$1985 / 1980$} & \multicolumn{3}{|c|}{$1988 / 1985$} \\
\hline U.S. & Germany & Japan & U.S. & Germany & Japan \\
\hline 125.5 & 74.2 & 94.9 & 110.1 & 172.3 & 150.2 \\
\hline 120.2 & 79.5 & 95.5 & 107.7 & 174.3 & 175.2 \\
\hline 104.4 & 93.3 & 99.4 & 102.2 & 98.9 & 85.7 \\
\hline
\end{tabular}

\section{Source: Appendix Tables C4 through C6}

That 14 per cent fall in the export/domestic price ratio for Japan between 1985 and 1988 suggests that there must have been a very large decline in relative margins on exports.

A similar set of identically weighted export and domestic price indexes was used in Kravis and Lipsey (1977a and 1977b) to study separately the impact of exchange-rate changes and of differences in inflation rates between countries on ratios of export to domestic prices from the early 1950 s through the mid-1970s. We interpreted changes in those ratios, as we do here, as evidence of changes in margins on export sales relative to those on domestic sales. U.S. export margins appear to be sensitive to changes in the U.S. exchange rate with the $D M$ and the Yen, and also to changes in relative infla- 
tion rates between the U.S. and the U.K. German export margins were less we 11 explained but responded to differences in inflation rates between Germany and the U.S., the U.K., Japan, and France. Japanese export margins, in the period of more stable exchange rates, responded more to European and U.S. business cycle movements than to exchange rates, but in the 1970 s began to respond to exchange rate changes as we11. The reactions to exchange rates and inflation rates could be summarized as a consistent response to changes in real exchange rates, over the whole period for the U.S. and Germany, and in the 1970 s for Japan as we 11 . The estimates covering a11 Japanese manufactures for what Marston (1989) refers to as PTM elasticities, are somewhat lower than his for individual products in the 1980s, but suggest that the phenomenon is not a new one.

\section{Conciuding Remarks}

Aside from the indexes for 1953-1964, drawn at least partially from our own data collection, all the indexes shown here are calculated from official, publicly available, data. Therefore, aside from possible additions to the country coverage mentioned earlier, further updating of the weighting, and a shift to a quarterly basis in place of the annual indexes presented here, most major improvements in the data would require actions by the official agencies producing the data. An exception, open to outside scholars, might be an extension of the hedonic price calculations to countries other than the United States.

Among the improvements in the official data that would be useful would be extension of the coverage of price series in countries for which there are major gaps in the data. French data are among the poorest in this respect among the countries we cover. In addition, the calculation of export and 
import price indexes based on price, rather than unit value, data, is still confined to a small group of countries, although the recent attention to "pricing-to-market" and pass-through issues suggests that there is a great deal to be learned by having separate domestic and international price data. There are, in addition, two other types of issues involving the quality of official price data that have not been extensively addressed, although both were discussed in Kravis and Lipsey (1971). One is the treatment of intracompany trade which, with the increase in the internationalization of firms and the increasing share in trade of the kinds of products in which international transactions tend to be internal to firms, is now a very large part of developed countries' trade. It is not clear to what degree the prices reported for such trade are artificial and to what degree they therefore distort export and import price measures. The principle suggested in Kravis and Lipsey (1971) was to use the price in the first arms length sale in a country in preference to intracompany prices, where that is possible, and we still believe that is the appropriate practice. For a U.S. export, for example, it would be the price at which the U.S. wholesale or retail trade affiliate in a country sold the product rather than the price at which a U.S. manufacturer sold to its overseas subsidiary. And for a U.S. import it would be, for example, the price at which a Japanese car was sold to an unaffiliated buyer in the U.S. rather than the price at which the Japanese manufacturer "sold" it to its U.S. sales affiliate.

Another type of question is raised by the very small extent to which U.S. firms admit selling at different prices at home and abroad, in contrast to the large differences reported by foreign firms. While it is conceivable that U.S. company trading policies are very different in this respect from those of 
other countries, it is also possible that since the export and domestic prices are collected by the same agency in rather similar ways, companies tend to report the same prices. For this reason, as well as others that have at times been suggested to price collection agencies, even for domestic price collection, it would be wise to collect prices not only from sellers, but also from purchasers. 


\section{References}

Angermann, Oswald (1980), "External Terms of Trade of the Federal Republic of Germany Using Different Methods of Deflation," Review of Income and Wealth, Series 26, No. 4, December.

Arndt, Sven W., and J. David Richardson (1987), Real-Financial Linkages Among Open Economies, Cambridge, MIT Press, pp. 49-70.

Baldwin, Richard E. (1988), "Hysteresis in Import Prices: The Beachhead Effect," American Economic Review, Vo 1. 78, No. 4, September, pp. 773-85. Bushe, Dennis M., Irving B. Kravis, and Robert E. Lipsey (1986), "Prices, Activity, and Machinery Exports: An Analysis Based on New Price Data," Review of Economics and Statistics, Vol. LXVIII, No. 2, May, pp. 248-255. Cartwright, David W. (1986), "Improved Deflation of Purchases of Computers," Survey of Current Business, vol. 66, No. 3, March. Cartwright, David W., and Scott D. Smith (1988), "Deflators for Purchases of Computers in GNP: Revised and Extended Estimates, 1983-88, "Survey of Current Business, Vol. 68, No. 11, November. Crouhy-Veyrac, Li]iane, Michel Crouhy, and Jacques Melitz (1980), "More About the Law of One Price," Institut National de la Statistique et des Sciences Economique, Serie des documents de travai1, No. 8002, March. Dornbusch, Rudiger (1987), "Exchange Rates and Prices," American Economic Review, Vol. 77, No. 1, March, pp. 93-106.

Goldstein, Morris, and Mohsin S. Khan (1985), "Income and Price Effects in Foreign Trade," in Jones and Kenen (1985), Vol. II, pp. 1041-1105. Gordon, Robert J. (1990), The Measurement of Durable Goods Prices, Chicago, University of Chicago Press. 
Haberler, Gottfried (1959), International Trade and Economic Development,

50th Anniversary Commemoration Lectures, National Bank of Egypt.

Jones, Ronald W., and Peter B. Kenen (1985), Handbook of International

Economics, Amsterdam, North Holland.

Kalter, R.J. (1978), "The Effect of Exchange Rate Changes Upon International

Price Discrimination," International Finance Discussion Papers 122, Board

of Governors of the Federal Reserve System, August.

Kravis, Irving B., and Robert E. Lipsey (1971), Price Competitiveness in

World Trade, New York, National Bureau of Economic Research.

and (1972), "The Elasticity of

Substitution as a Variable in World Trade," in Donald J. Daly, Ed.,

International Comparisons of Prices and Output, Studies in Income and

Wealth, Vol. 37, New York, National Bureau of Economic Research,

pp. 369-398.

and

(1974), "Export Prices and Price

Proxies," in Nancy D. Ruggles (Ed.), The Role of the Computer in Economic

and Social Research in Latin America, New York, National Bureau of

Economic Research.

and

(1977a), "Export Prices and the

Transmission of Inflation," American Economic Review, Vol. 67, No. 1 ,

February, pp. 155-163.

and (1977b), "Export and Domestic Prices

Under Inflation and Exchange Rate Movements," NBER Working Paper 176, May. and (1978), "Price Behavior in the Light

of Balance of Payments Theories," Journal of International Economics,

May. 
Kravis, Irving B., Robert E. Lipsey, and Dennis Bushe (1980), "Prices and Market Share in International Machinery Trade," NBER Working Paper 521, July.

Kravis, Irving B., and Robert E. Lipsey (1982), "Prices and Market Shares in the International Machinery Trade," Review of Economics and Statistics, Vo1. LXIV, No. 1, February, Pp. 110-116. (1984), "Prices and Terms of Trade for

Developed Country Exports of Manufactured Goods," in Bela Csikos-Nagy, Douglas Hague, and Graham Hall, eds. The Economics of Relative Prices, New York, St. Martin's Press, pp. 415-445. Krugman, Paul (1987), "Pricing to Market When the Exchange Rate Changes," in Arndt and Richardson (1987).

Lipsey, Robert E. (1963), Price and Quantity Trends in Foreign Trade of the United States, Princeton, Princeton University Press for the NBER. Mann, Catherine L. (1986), "Prices, Profit Margins, and Exchange Rates," Federal Reserve Bulletin, Vol. 72, No. 6, June, pp. 366-379. Marston, Richard (1989), "Pricing to Market in Japanese Manufacturing," NBER Working Paper 2905, March. Murphy, Edward E. (1972), "A Comparison of the Bureau of Labor Statistics' Indexes of Export Prices for Selected U.S. Products with Unit Value and Wholesale Price Indexes," 1971 Proceedings of the Business and Economic Statistics Section, American Statistical Association. National Bureau of Economic Research, Price Statistics Review Committee (1961), The Price Statistics of the Federal Government, Report to the office of Statistical Standards, Bureau of the Budget, New York, NBER. Norsworthy, J.R., and Show-Ling Jang (1990), "Cost Function Estimation of 
Quality Change Embodied in Inputs: The Use of Semiconductors in Computers and Telecommunications Equipment," Paper prepared for NBER Conference on Research in Income and Wealth Workshop on Price Measurements and Their Uses, March 22 and 23, Washington, DC. Ohno, Kenichi (1989), "Export Pricing Behavior of Manufacturing: A U.S.-Japan Comparison," International Monetary Fund Staff Papers, Vo1. 36, No. 3, September, pp. 550-579.

Rostin, W. (1974), "Die Indices der Aussenhandelspreise auf Basis 1970," Wirtschaft und Statistik, 6, pp. 387-394.

Summers, Robert (1973), "International Price Comparisons based upon Incomplete Data," Review of Income and Wea1th, Series 19, No. 1, March, pp. 1-16.

Viner, Jacob (1953), International Trade and Economic Development, Lectures Delivered at the National University of Brazil, Oxford, Clarendon Press. 
Robert E. Lipsey, Linda Molinari, and Irving B. Kravis

\section{Footnotes}

1See, for example, NBER Price Statistics Review Committee (1961), Kravis and Lipsey (1971) and (1974), and Murphy (1972).

${ }^{2}$ The profit margin interpretation and the literature on the related "pass-through" issue are reviewed in Mann (1986).

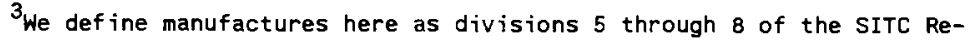
vision 1. The most serious omission for comparison with domestic industrial data is of manufactured foods, although there are also some other minor omissions, some of which were rectified in Revision 2 of the SITC. We did not adopt them here because the indexes could not be recalculated to match the later classification without a major effort.

${ }^{4}$ Kravis and Lipsey (1972), (1977a), (1977b) and (1982) and Bushe, Kravis and Lipsey (1986).

${ }^{5}$ For example, Kravis and Lipsey (1978).

Within the developed market economy groups, of the $\$ 217$ billion of manufactures exports by countries we did not cover, the largest omitted country was Italy, with $\$ 68$ billion in exports, followed by Belgium/Luxembourg with $\$ 40$ billion and Switzerland with $\$ 32$ billion. Other European countries, for which at least some detailed domestic producer or wholesale price data could probably be obtained with sufficient efforts, were the sources of another $\$ 67$ billion. Thus, Europe as a whole accounted for 95 per cent of the manufactured exports of developed market econoimies that we did not cover.

of the $\$ 265$ billion in manufactured exports by other groups of countries in 1985, 22 per cent of the total, over 60 per cent were exports by developing countries, and the rest were from centrally planned economies. The $\$ 167$ 
billion from developing countries were concentrated in Southeast Asian countries. More than 40 per cent were from Hong Kong, Korea, and Singapore, and the concentration in Asia would be even higher if the figures included Taiwan, omitted from UN tabulations.

${ }^{7}$ For a detailed discussion of the relationship to the covariances, see Lipsey (1963), Pp. 85-90.

${ }^{8}$ Goldstein and Khan (1985). For an example using our price data, see Kravis, Lipsey, and Bushe (1980). 
Robert E. Lipsey, Linda Molinari, and Irving B. Kravis

\section{APPENDIX A}

Sources of Price Data

\section{Export Prices}

The German price data appear in Statistisches Bundesamt, Preise, Löhne, Wirtschaftsrechnungen, Reihe 1, Preise and Preisindizes für Aussenhandelsgüter. A brief description is given in Angermann (1980), and in articles in Wirtschaft und Statistik, such as Rost in (1974). The Japanese export price data are published in the Price Indexes Annual, earlier the Export and Import Price Indexes Annual, of the Bank of Japan. The U.S. export price data are from releases of the U.S. Bureau of Labor Statistics entitled, "U.S. Import and Export Price Indexes." A brief description of these is given in Comparisons of U.S., German, and Japanese Export Price Indexes, BLS Bulletin $2046,1980$.

Export price data for other countries were more fragmentary. Two publications of the Central Bureau of Statistics of the Netherlands, Maandstatistiek van de Binnenlandse Handel and Bijvoegsel Maandstatistiek van de Prijzen, provided export price data with incomplete but increasing coverage.

For the U.K., there are virtually no export price data outside the period covered by Kravis and Lipsey (1971). The exception is a set of export price indexes for products in SITC 7 for 1976 through 1979, part of an experimental program that was later discontinued.

Swedish export prices are reported in various issues of publications of the Central Bureau of Statistics, the latest of which is "Pricindex $i$ producent-och importled 1988" (1989). Some of the indexes are based on unit value data, and we tried to avoid using these as far as possible, preferring 
the data on domestic prices mentioned below.

\section{Domestic Prices}

For Canada, wholesale price indexes are from tapes provided by Statistics Canada.

Domestic price data for the U.S. were price series at the most detailed level from a BLS wholesale Price Index tape. For the U.K., some individual series were collected from publications of the Board of Trade and the Department of Trade and Industry. However, the U.K. did not publish individual series for most machinery or "engineering" groups for many years. For these, we used a set of indexes at the two-digit SITC level calculated for us by the Board of Trade from detailed price data using OECD weights we supplied. For later years, we could not obtain these series and were obliged to use a similar set of two-digit indexes calculated by the Department of Trade and Industry based on U.K. export weights. For more recent periods, beginning in the 1970s, fairly detailed price indexes. for machinery have been published in annual price articles such as "Wholesale Price Indices in 1981," in British Business, 7 May 1982, and "Wholesale Prices in 1982," in British Business, 6 May 1983.

The German domestic price indexes are individual series published in Preise, Löhne, Wirtschaftsrechnungen, Reihe 3, Preise und Preisindixes für industrielle Produkte, Index der Erzeugerpreise, and Reihe 8 , Index der Grosshandelsverkaufspreise (Statistisches Bundesamt, Wiesbaden). The Japanese domestic price indexes are also individual series from the Price Indexes Annual and the Wholesale Price Indexes Annual, published by the Bank of Japan. Swedish domestic producers price indexes are from the source listed above for export price indexes, but many more detailed indexes are available for domestic prices. 
French prices through 1977 for a large number of products were kindly supplied on tape by Dr. Liliane Crouhy-Veyrac of the Department Economie, Centre d'Enseignement Superior des Affaires. These data were the basis for Crouhy-Veyrac, Crouhy, and Melitz (1980). These data were supplemented by information from "Les Indices des Prix de Gros Base 100 en 1962," the Bulletin Mensuel de Statistique de la France and the Annuaire Statistique de 1a France, al1 published by INSEE.

The other main set of data are the hedonic price indexes substituted for conventional price series in our calculation of the quality-adjusted price index. These indexes are originally from a number of sources, but most of them were collected in Gordon (1990). The exceptions were the price indexes for computers from Cartwright (1986) and Cartwright and Smith (1988) and those for semiconductors, from Norsworthy and Jang (1990). 
APPENDIX B

Indexes Based on Weights of OECD Exports to the Wor ld or to Developing Countries 


\section{Appendix Table 81}

Price Indexes For Manufactured Exports by Developed Countries All Manufactures (SITC 5-8) and SITC Divisions, U.S. Dollars 1963 Weights

(Annual Averages, 1975=100)

\begin{tabular}{|c|c|c|c|c|c|}
\hline YEAR & $\begin{array}{c}\text { All } \\
\text { Manufactures }\end{array}$ & SITC5 & SITC6 & SITC7 & SITCB \\
\hline 1953 & 47.8 & 57.0 & 47.6 & 45.8 & 49.5 \\
\hline 1954 & 47.4 & 57.4 & 46.5 & 45.7 & 49.1 \\
\hline 1955 & 48.2 & 56.2 & 48.1 & 46.3 & 49.2 \\
\hline 1956 & 49.5 & 55.5 & 50.1 & 47.9 & 49.8 \\
\hline 1957 & 50.7 & 56.2 & 50.8 & 49.5 & 50.3 \\
\hline 1958 & 50.3 & 55.8 & 48.7 & 50.0 & 50.4 \\
\hline 1959 & 50.1 & 54.6 & 49.1 & 50.0 & 50.2 \\
\hline 1960 & 50.3 & 54.4 & 49.5 & 50.0 & 50.7 \\
\hline 1961 & 50.8 & 54.6 & 49.4 & 50.9 & 51.7 \\
\hline 1962 & 50.4 & 53.0 & 48.3 & 51.0 & 52.3 \\
\hline 1963 & 50.6 & 52.7 & 48.4 & 51.3 & 52.8 \\
\hline 1964 & 51.4 & 52.4 & 50.0 & 51.9 & 53.6 \\
\hline 1965 & 52.3 & 52.5 & 50.8 & 52.9 & 54.5 \\
\hline 1966 & 53.4 & 52.7 & 52.2 & 54.1 & 56.0 \\
\hline 1967 & 53.5 & 52.5 & 51.7 & 54.7 & 56.9 \\
\hline 1968 & 53.0 & 50.9 & 51.6 & 54.1 & 56.8 \\
\hline 1969 & 54.6 & 50.6 & 53.6 & 55.7 & 58.4 \\
\hline 1970 & 58.0 & 52.7 & 57.3 & 59.6 & 61.4 \\
\hline $\begin{array}{l}1971 \\
1972\end{array}$ & $\begin{array}{l}61.4 \\
66.7\end{array}$ & $\begin{array}{l}54.8 \\
58.3\end{array}$ & $\begin{array}{l}59.2 \\
64.6\end{array}$ & $\begin{array}{l}64.4 \\
70.0\end{array}$ & $\begin{array}{l}65.0 \\
71.3\end{array}$ \\
\hline 1973 & 76.0 & 65.2 & 77.0 & 77.9 & 81.0 \\
\hline 1974 & 89.6 & 86.3 & 94.4 & 87.2 & 90.9 \\
\hline 1975 & 100.0 & 100.0 & 100.0 & 100.0 & 100.0 \\
\hline 1976 & 102.3 & 100.2 & 103.9 & 102.3 & 101.3 \\
\hline $\begin{array}{l}1977 \\
1978\end{array}$ & $\begin{array}{l}110.7 \\
125.7\end{array}$ & $\begin{array}{l}106.3 \\
117.6\end{array}$ & $\begin{array}{l}111.3 \\
124.9\end{array}$ & $\begin{array}{l}111.8 \\
128.7\end{array}$ & $\begin{array}{l}110.3 \\
126.6\end{array}$ \\
\hline 1979 & 143.8 & 142.0 & 144.0 & 145.3 & 141.3 \\
\hline 1980 & 161.5 & 165.2 & 161.8 & 162.3 & 157.9 \\
\hline 1981 & 155.4 & 158.7 & 154.0 & 156.6 & 153.0 \\
\hline 1982 & 151.4 & 152.9 & 146.8 & 155.2 & 148.6 \\
\hline 1983 & 142.3 & 146.3 & 140.9 & 152.4 & 146.5 \\
\hline 1984 & 142.4 & 141.6 & 136.8 & 147.0 & 141.4 \\
\hline 1985 & 143.3 & 142.6 & 136.0 & 148.8 & 143.1 \\
\hline 1986 & 171.6 & 166.4 & 159.5 & 180.1 & 178.6 \\
\hline 1987 & 194.9 & 186.8 & 181.3 & 204.8 & 203.4 \\
\hline 1988 & 212.6 & 207.0 & 205.8 & 218.1 & 216.6 \\
\hline
\end{tabular}




\section{Appendix Table B2}

Price Indexes For Manufactured Exports by Developed Countries All Manufactures (SITC 5-8) and SITC Divisions, U.S. Dollars 1975 Weights

(Annual Averages, 1975=100)

\begin{tabular}{|c|c|c|c|c|c|}
\hline YEAR & $\begin{array}{c}\text { All } \\
\text { Manufactures }\end{array}$ & SITC5 & SITC6 & SITC7 & SITC8 \\
\hline 1953 & 49.4 & 58.9 & & 49.5 & 49.2 \\
\hline 1954 & 48.9 & 59.2 & 45.5 & 49.1 & 48.8 \\
\hline $\begin{array}{l}1955 \\
1956\end{array}$ & $\begin{array}{l}49.3 \\
50.6\end{array}$ & $\begin{array}{l}57.6 \\
56.7\end{array}$ & $\begin{array}{r}46.9 \\
49.3\end{array}$ & $\begin{array}{l}49.4 \\
51.0\end{array}$ & $\begin{array}{l}48.8 \\
49.2\end{array}$ \\
\hline 1957 & 51.8 & 57.1 & 50.1 & 52.8 & 49.7 \\
\hline 1958 & 51.1 & 56.3 & 47.9 & 52.8 & 49.7 \\
\hline $\begin{array}{l}1959 \\
1960\end{array}$ & $\begin{array}{l}50.8 \\
50.8\end{array}$ & $\begin{array}{l}54.9 \\
54.6\end{array}$ & $\begin{array}{l}48.1 \\
48.4\end{array}$ & $\begin{array}{l}52.4 \\
52.2\end{array}$ & $\begin{array}{l}49.5 \\
50.0\end{array}$ \\
\hline 1961 & 51.2 & 54.6 & 48.4 & 52.8 & 51.1 \\
\hline $\begin{array}{l}1962 \\
1963\end{array}$ & $\begin{array}{l}50.7 \\
50.6\end{array}$ & $\begin{array}{l}52.5 \\
52.0\end{array}$ & 47.2 & 52.6 & 51.7 \\
\hline 1964 & 51.2 & 51.6 & 48.5 & 53.0 & 52.9 \\
\hline 1965 & 51.9 & 51.6 & 49.1 & 53.8 & 53.9 \\
\hline 1966 & 52.9 & 51.5 & 50.1 & 55.0 & 55.4 \\
\hline 1967 & 53.1 & 51.2 & 49.8 & 55.6 & 56.3 \\
\hline 1968 & 52.8 & 49.6 & 49.6 & 55.5 & 56.1 \\
\hline 1969 & 54.2 & 49.2 & 51.6 & 57.1 & 57.7 \\
\hline $\begin{array}{l}1970 \\
1971\end{array}$ & $\begin{array}{l}57.6 \\
61.0\end{array}$ & $\begin{array}{l}51.1 \\
53.1\end{array}$ & $\begin{array}{l}55.7 \\
57.6\end{array}$ & $\begin{array}{l}60.6 \\
65.2\end{array}$ & $\begin{array}{l}60.7 \\
64.4\end{array}$ \\
\hline 1972 & 66.4 & 56.9 & 63.1 & 70.9 & 71.0 \\
\hline 1973 & 76.2 & 64.9 & 76.1 & 79.2 & 81.1 \\
\hline 1974 & 90.0 & 87.9 & 94.6 & 86.5 & 90.7 \\
\hline 1975 & 100.0 & 100.0 & 100.0 & 100.0 & 100.0 \\
\hline 1976 & 102.4 & 99.7 & 103.2 & 102.7 & 101.2 \\
\hline 1977 & 110.3 & 105.3 & 110.4 & 111.1 & 110.4 \\
\hline 1978 & 125.9 & 117.0 & 126.2 & 127.7 & 127.0 \\
\hline 1979 & 142.7 & 142.9 & 144.6 & 141.3 & 141.8 \\
\hline 1980 & 158.5 & 164.7 & 161.6 & 155.3 & 158.3 \\
\hline $\begin{array}{l}1981 \\
1982\end{array}$ & $\begin{array}{l}152.5 \\
148.3\end{array}$ & $\begin{array}{l}155.4 \\
148.2\end{array}$ & $\begin{array}{l}152.7 \\
145.8\end{array}$ & $\begin{array}{l}151.6 \\
149.4\end{array}$ & $\begin{array}{l}150.4 \\
145.3\end{array}$ \\
\hline 1983 & 144.6 & 141.7 & 139.2 & 147.7 & 142.2 \\
\hline $\begin{array}{l}1984 \\
1985\end{array}$ & $\begin{array}{l}139.8 \\
140.4\end{array}$ & $\begin{array}{l}136.2 \\
136.6\end{array}$ & $\begin{array}{l}134.7 \\
133.8\end{array}$ & $\begin{array}{l}143.1 \\
144.4\end{array}$ & 136.5 \\
\hline 1986 & 170.4 & 161.5 & 160.0 & 176.3 & 174.1 \\
\hline 1987 & 193.1 & 183.6 & 181.4 & 199.3 & 199.1 \\
\hline 1988 & 209.1 & 202.6 & 204.3 & 211.7 & 211.4 \\
\hline
\end{tabular}




\section{Appendix Table $\mathrm{B3}$}

Price Indexes For Manufactured Exports

by Developed Countries to Developing Countries

Al1 Manufactures (SITC 5-8) and SITC Divisions, U.S. DolTars 1963 Weights

(Annual Averages, 1975=100)

\begin{tabular}{|c|c|c|c|c|c|}
\hline YEAR & $\begin{array}{c}\text { ATT } \\
\text { Manufactures }\end{array}$ & SITC5 & SITC6 & SITC7 & SITCB \\
\hline $\begin{array}{l}1953 \\
1954\end{array}$ & $\begin{array}{l}50.6 \\
50.3\end{array}$ & $\begin{array}{l}57.9 \\
58.5\end{array}$ & $\begin{array}{l}50.1 \\
48.9\end{array}$ & $\begin{array}{l}48.1 \\
48.0\end{array}$ & $\begin{array}{l}55.6 \\
55.3\end{array}$ \\
\hline $\begin{array}{l}1955 \\
1956 \\
1957\end{array}$ & $\begin{array}{l}50.9 \\
52.5 \\
54.0\end{array}$ & $\begin{array}{l}57.3 \\
56.5 \\
57.6\end{array}$ & $\begin{array}{l}50.2 \\
52.8 \\
53.7\end{array}$ & $\begin{array}{l}48.6 \\
50.7 \\
52.7\end{array}$ & $\begin{array}{l}55.4 \\
56.1 \\
56.6\end{array}$ \\
\hline $\begin{array}{l}1958 \\
1959\end{array}$ & $\begin{array}{l}53.7 \\
53.6\end{array}$ & $\begin{array}{l}57.4 \\
56.2\end{array}$ & $\begin{array}{l}51.3 \\
51.7\end{array}$ & $\begin{array}{l}53.2 \\
53.4\end{array}$ & $\begin{array}{l}56.4 \\
56.2\end{array}$ \\
\hline 1960 & 53.6 & 56.1 & 52.1 & 53.3 & 56.7 \\
\hline 1961 & 53.9 & 56.2 & 51.9 & 54.0 & 57.3 \\
\hline $\begin{array}{l}1962 \\
1963\end{array}$ & $\begin{array}{l}53.4 \\
53.4\end{array}$ & $\begin{array}{l}55.1 \\
54.9\end{array}$ & $\begin{array}{l}50.6 \\
50.6\end{array}$ & $\begin{array}{l}53.9 \\
54.1\end{array}$ & $\begin{array}{l}57.8 \\
58.1\end{array}$ \\
\hline $\begin{array}{l}1964 \\
1965\end{array}$ & $\begin{array}{l}54.1 \\
54.9\end{array}$ & $\begin{array}{l}54.7 \\
55.2\end{array}$ & $\begin{array}{l}51.9 \\
52.5\end{array}$ & $\begin{array}{l}54.7 \\
55.6\end{array}$ & $\begin{array}{l}58.6 \\
59.5\end{array}$ \\
\hline $\begin{array}{l}1966 \\
1967\end{array}$ & $\begin{array}{l}56.0 \\
56.2\end{array}$ & $\begin{array}{l}55.4 \\
55.3\end{array}$ & $\begin{array}{l}53.6 \\
53.3\end{array}$ & $\begin{array}{l}56.9 \\
57.6\end{array}$ & $\begin{array}{l}61.1 \\
61.9\end{array}$ \\
\hline $\begin{array}{l}1968 \\
1969\end{array}$ & $\begin{array}{l}55.7 \\
57.1\end{array}$ & $\begin{array}{l}53.7 \\
53.4\end{array}$ & $\begin{array}{l}53.0 \\
54.9\end{array}$ & $\begin{array}{l}56.9 \\
58.5\end{array}$ & $\begin{array}{l}61.7 \\
63.4\end{array}$ \\
\hline 1970 & 60.0 & 55.1 & 58.0 & 62.0 & 65.7 \\
\hline 1971 & 63.3 & 57.3 & 60.0 & 66.4 & 68.5 \\
\hline 1972 & 68.3 & 60.7 & 65.7 & 71.5 & 74.5 \\
\hline $\begin{array}{l}1973 \\
1974\end{array}$ & $\begin{array}{l}76.2 \\
89.3\end{array}$ & $\begin{array}{l}67.0 \\
85.2\end{array}$ & $\begin{array}{l}77.1 \\
94.3\end{array}$ & $\begin{array}{l}78.0 \\
87.5\end{array}$ & $\begin{array}{l}82.5 \\
91.4\end{array}$ \\
\hline 1975 & 100.0 & 100.0 & 100.0 & 100.0 & 100.0 \\
\hline $\begin{array}{l}1976 \\
1977 \\
1978\end{array}$ & $\begin{array}{l}102.3 \\
110.8 \\
126.4\end{array}$ & $\begin{array}{l}100.4 \\
106.8 \\
119.5\end{array}$ & $\begin{array}{l}103.7 \\
111.8 \\
127.2\end{array}$ & $\begin{array}{l}102.6 \\
111.8 \\
128.5\end{array}$ & $\begin{array}{c}101.7 \\
110.2 \\
125.9\end{array}$ \\
\hline $\begin{array}{l}1979 \\
1980\end{array}$ & $\begin{array}{l}143.0 \\
161.1\end{array}$ & $\begin{array}{l}141.5 \\
164.3\end{array}$ & $\begin{array}{l}143.5 \\
161.6\end{array}$ & $\begin{array}{l}144.3 \\
162.2\end{array}$ & $\begin{array}{l}140.1 \\
157.6\end{array}$ \\
\hline $\begin{array}{l}1981 \\
1982\end{array}$ & $\begin{array}{l}159.7 \\
156.0\end{array}$ & $\begin{array}{l}162.3 \\
157.6\end{array}$ & $\begin{array}{l}158.7 \\
151.3\end{array}$ & $\begin{array}{l}161.1 \\
160.2\end{array}$ & $\begin{array}{l}157.5 \\
152.1\end{array}$ \\
\hline 1983 & 152.4 & 151.6 & 145.7 & 158.1 & 150.3 \\
\hline $\begin{array}{l}1984 \\
1985\end{array}$ & $\begin{array}{l}148.7 \\
150.4\end{array}$ & $\begin{array}{l}147.1 \\
149.4\end{array}$ & $\begin{array}{l}143.0 \\
142.8\end{array}$ & $\begin{array}{l}154.0 \\
156.4\end{array}$ & $\begin{array}{l}146.5 \\
149.3\end{array}$ \\
\hline 1986 & 176.6 & 173.2 & 166.2 & 184.1 & 182.5 \\
\hline 1987 & 196.8 & 191.9 & 184.9 & 205.4 & 204.8 \\
\hline 1988 & 213.8 & 211.4 & 206.9 & 219.1 & 218.1 \\
\hline
\end{tabular}




\section{Appendix Tabie $B 4$}

Price Indexes For Manufactured Exports

by Developed Countries to Developing Countries

All Manufactures (SITC 5-8) and SITC Divisions, U.S. Dollars 1975 Weights

(Annual Averages, $1975=100$ )

\begin{tabular}{|c|c|c|c|c|c|}
\hline YEAR & $\begin{array}{c}\text { A } 11 \\
\text { Manufactures }\end{array}$ & SITC5 & SITC6 & SITC7 & SITC8 \\
\hline $\begin{array}{l}1953 \\
1954\end{array}$ & $\begin{array}{l}51.9 \\
51.3\end{array}$ & $\begin{array}{l}58.7 \\
59.1\end{array}$ & $\begin{array}{l}49.6 \\
47.6\end{array}$ & $\begin{array}{l}50.1 \\
49.9\end{array}$ & $\begin{array}{l}53.4 \\
52.9\end{array}$ \\
\hline $\begin{array}{l}1955 \\
1956\end{array}$ & $\begin{array}{l}51.4 \\
53.5\end{array}$ & $\begin{array}{l}57.4 \\
56.2\end{array}$ & $\begin{array}{l}48.9 \\
53.5\end{array}$ & $\begin{array}{l}50.1 \\
52.1\end{array}$ & $\begin{array}{l}52.8 \\
53.1\end{array}$ \\
\hline 1957 & 55.2 & 56.6 & 54.8 & 54.2 & 53.2 \\
\hline 1958 & 53.8 & 55.3 & 50.4 & 54.1 & 53.0 \\
\hline 1959 & 53.5 & 53.9 & 51.2 & 53.9 & 53.2 \\
\hline 1960 & 53.5 & 53.8 & 51.3 & 53.7 & 53.8 \\
\hline 1961 & 53.5 & 53.7 & 50.9 & 54.1 & 54.5 \\
\hline 1962 & 52.7 & 51.8 & 49.2 & 53.8 & 54.9 \\
\hline 1963 & 52.5 & 51.2 & 49.1 & 53.8 & 55.3 \\
\hline 1964 & 53.0 & 51.3 & 50.0 & 54.1 & 55.9 \\
\hline 1965 & 53.5 & 51.4 & 50.2 & 54.9 & 56.6 \\
\hline 1966 & 54.3 & 51.2 & 50.9 & 56.1 & 57.8 \\
\hline 1967 & 54.6 & 51.0 & 51.1 & 56.8 & 58.8 \\
\hline 1968 & 54.9 & 50.1 & 51.2 & 57.5 & 59.8 \\
\hline 1969 & 56.3 & 49.6 & 53.2 & 59.1 & 61.5 \\
\hline 1970 & 59.0 & 50.7 & 56.7 & 62.3 & 63.9 \\
\hline 1971 & 61.6 & 51.9 & 58.2 & 66.1 & 66.5 \\
\hline 1972 & 66.8 & 55.2 & 63.9 & 71.6 & 72.7 \\
\hline 1973 & 77.1 & 63.6 & 77.7 & 80.1 & 83.0 \\
\hline 1974 & 91.4 & 85.5 & 97.9 & 89.4 & 92.9 \\
\hline 1975 & 100.0 & 100.0 & 100.0 & 100.0 & 100.0 \\
\hline 1976 & 103.2 & 100.3 & 105.0 & 103.8 & 102.7 \\
\hline 1977 & 110.5 & 104.9 & 111.7 & 112.0 & 110.6 \\
\hline 1978 & 127.2 & 115.8 & 130.6 & 127.8 & 126.9 \\
\hline 1979 & 139.7 & 137.7 & 144.7 & 139.8 & 135.7 \\
\hline 1980 & 151.8 & 156.4 & 159.0 & 151.3 & 147.0 \\
\hline 1981 & 152.9 & 154.9 & 158.7 & 151.3 & 148.6 \\
\hline 1982 & 149.0 & 148.4 & 151.8 & 149.2 & 144.0 \\
\hline 1983 & 145.8 & 143.9 & 144.2 & 148.0 & 142.8 \\
\hline 1984 & 142.5 & 140.0 & 141.9 & 144.4 & 139.5 \\
\hline $\begin{array}{l}1985 \\
1986\end{array}$ & $\begin{array}{l}143.4 \\
169.9\end{array}$ & $\begin{array}{l}140.2 \\
159.8\end{array}$ & $\begin{array}{l}141.0 \\
160.9\end{array}$ & $\begin{array}{l}146.2 \\
176.9\end{array}$ & $\begin{array}{r}141.4 \\
173.0\end{array}$ \\
\hline 1987 & 190.4 & 180.5 & 178.5 & 198.9 & 192.9 \\
\hline 1988 & 208.9 & 199.9 & 207.4 & 212.8 & 205.2 \\
\hline
\end{tabular}




\section{Appendix Table B5}

Price Indexes for Manufactured Exports by Germany, U.S. Dollars, 1963 Weights of OECD Exports to Wor ld

(Annua) Averages, 1975=100)

\begin{tabular}{|c|c|c|c|c|c|}
\hline & $\begin{array}{c}\text { A } 71 \\
\text { Manufactures }\end{array}$ & SITC 5 & SITC 6 & SITC 7 & SITC 8 \\
\hline 1953 & 36.2 & 43.9 & 37.7 & 34.7 & 32.5 \\
\hline 1954 & 35.4 & 43.4 & 36.6 & 33.9 & 32.1 \\
\hline 1955 & 36.0 & 42.4 & 38.3 & 34.4 & 32.3 \\
\hline 1956 & 36.4 & 41.6 & 38.8 & 34.9 & 32.6 \\
\hline 1957 & 37.0 & 41.8 & 39.3 & 35.5 & 33.3 \\
\hline 1958 & 37.1 & 42.4 & 38.9 & 35.7 & 33.5 \\
\hline 1959 & 36.5 & 41.7 & 38.6 & 35.0 & 33.1 \\
\hline 1960 & 36.7 & 41.0 & 39.3 & 35.1 & 33.5 \\
\hline 1961 & 38.6 & 42.6 & 40.9 & 37.2 & 35.9 \\
\hline 1962 & 39.3 & 42.1 & 41.0 & 38.3 & 37.3 \\
\hline 1963 & 39.6 & 42.7 & 41.2 & 38.6 & 37.8 \\
\hline 1964 & 40.2 & 42.3 & 42.7 & 38.8 & 38.6 \\
\hline 1965 & 41.3 & 42.3 & 43.8 & 40.0 & 39.9 \\
\hline 1966 & 42.1 & 42.5 & 44.7 & 40.9 & 41.2 \\
\hline 1967 & 41.9 & 42.3 & 43.5 & 41.1 & 41.8 \\
\hline 1968 & 41.6 & 41.1 & 43.3 & 40.9 & 41.7 \\
\hline 1969 & 43.4 & 41.1 & 45.1 & 43.3 & 43.5 \\
\hline 1970 & 49.1 & 45.7 & 51.2 & 49.0 & 48.8 \\
\hline 1971 & 53.6 & 48.9 & 53.7 & 55.1 & 54.2 \\
\hline 1972 & 60.2 & 53.8 & 59.5 & 62.4 & 62.5 \\
\hline 1973 & 76.9 & 68.2 & 78.4 & 78.3 & 79.1 \\
\hline 1974 & 90.8 & 92.4 & 96.1 & 87.6 & 89.0 \\
\hline 1975 & 100.0 & 100.0 & 100.0 & 100.0 & 100.0 \\
\hline 1976 & 101.3 & 98.6 & 101.8 & 101.8 & 101.0 \\
\hline 1977 & 111.8 & 107.6 & 109.3 & 114.6 & 112.6 \\
\hline $197 \mathrm{~B}$ & 130.7 & 123.5 & 127.0 & 135.0 & 132.7 \\
\hline 1979 & 152.3 & 142.9 & 150.0 & 157.0 & 150.0 \\
\hline 1980 & 164.0 & 158.0 & 162.6 & 166.9 & 162.8 \\
\hline 1981 & 138.4 & 136.1 & 136.1 & 141.2 & 136.6 \\
\hline 1982 & 134.8 & 129.2 & 132.8 & 138.2 & 132.9 \\
\hline 1983 & 130.4 & 123.1 & 126.9 & 134.9 & 129.7 \\
\hline 1984 & 120.8 & 114.2 & 118.7 & 124.4 & 119.1 \\
\hline 1985 & 120.1 & 114.2 & 117.4 & 124.0 & 118.1 \\
\hline 1986 & 162.0 & 151.1 & 151.0 & 172.5 & 163.7 \\
\hline 1987 & 195.7 & 177.6 & 177.6 & 213.1 & 201.2 \\
\hline 1988 & 207.7 & 185.4 & 195.2 & 222.2 & 209.5 \\
\hline
\end{tabular}




\section{Appendix Table $B 6$}

Price Indexes for Manufactured Exports by Germany, U.S. Dollars, 1975 Weights of OECD Exports to the World

(Annua) Averages, 1975=100)

\begin{tabular}{|c|c|c|c|c|c|}
\hline & $\begin{array}{c}\text { A11 } \\
\text { Manufactures }\end{array}$ & SITC 5 & SITC 6 & SITC 7 & SITC 8 \\
\hline $\begin{array}{l}1953 \\
1954\end{array}$ & $\begin{array}{l}36.7 \\
35.9\end{array}$ & $\begin{array}{l}46.0 \\
45.4\end{array}$ & $\begin{array}{l}37.1 \\
36.0\end{array}$ & $\begin{array}{l}35.6 \\
34.8\end{array}$ & $\begin{array}{l}33.4 \\
33.0\end{array}$ \\
\hline $\begin{array}{l}1955 \\
1956\end{array}$ & $\begin{array}{l}36.4 \\
36.8\end{array}$ & $\begin{array}{l}44.4 \\
43.5\end{array}$ & $\begin{array}{l}37.4 \\
37.9\end{array}$ & $\begin{array}{l}35.3 \\
35.8\end{array}$ & $\begin{array}{l}33.0 \\
33.2\end{array}$ \\
\hline $\begin{array}{l}1957 \\
1958\end{array}$ & $\begin{array}{l}37.3 \\
37.4\end{array}$ & $\begin{array}{l}43.6 \\
44.0\end{array}$ & $\begin{array}{l}38.5 \\
38.4\end{array}$ & $\begin{array}{l}36.3 \\
36.5\end{array}$ & $\begin{array}{l}34.0 \\
34.1\end{array}$ \\
\hline 1959 & 36.8 & 43.2 & 38.0 & 35.7 & 33.7 \\
\hline 1960 & 36.9 & 42.4 & 38.5 & 35.7 & 34.1 \\
\hline 1961 & 38.7 & 43.8 & 40.0 & 37.7 & 36.4 \\
\hline 1962 & 39.5 & 43.2 & 40.3 & 38.8 & 37.7 \\
\hline 1963 & 39.7 & 43.5 & 40.4 & 39.0 & 38.2 \\
\hline 1964 & 40.1 & 42.9 & 41.6 & 39.1 & 39.0 \\
\hline 1965 & 41.0 & 42.8 & 42.5 & 40.3 & 40.3 \\
\hline 1966 & 41.7 & 42.8 & 43.1 & 41.1 & 41.6 \\
\hline 1967 & 41.6 & 42.6 & 42.0 & 41.3 & 42.1 \\
\hline 1968 & 41.3 & 41.3 & 41.8 & 41.1 & 42.0 \\
\hline 1969 & 43.1 & 41.1 & 43.7 & 43.3 & 43.8 \\
\hline 1970 & 48.7 & 45.8 & 50.0 & 49.1 & 49.1 \\
\hline 1971 & 53.5 & 48.8 & 52.7 & 55.3 & 54.5 \\
\hline 1972 & 59.9 & 53.5 & 58.1 & 62.4 & 62.8 \\
\hline 1973 & 76.2 & 67.8 & 76.5 & 78.2 & 79.4 \\
\hline 1974 & 90.3 & 93.2 & 95.0 & 87.6 & 89.4 \\
\hline 1975 & 100.0 & 100.0 & 100.0 & 100.0 & 100.0 \\
\hline 1976 & 100.7 & 98.3 & 100.3 & 101.5 & 100.9 \\
\hline $\begin{array}{l}1977 \\
1978\end{array}$ & $\begin{array}{l}110.9 \\
129.9\end{array}$ & $\begin{array}{l}106.7 \\
122.0\end{array}$ & $\begin{array}{l}106.7 \\
125.4\end{array}$ & $\begin{array}{l}113.8 \\
133.9\end{array}$ & $\begin{array}{l}112.5 \\
132.2\end{array}$ \\
\hline 1979 & 151.4 & 142.4 & 147.5 & 156.3 & 149.2 \\
\hline 1980 & 162.6 & 156.8 & 159.3 & 166.1 & 161.3 \\
\hline 1981 & 137.4 & 134.2 & 134.4 & 140.4 & 135.0 \\
\hline 1982 & 134.0 & 127.2 & 132.4 & 137.3 & 130.9 \\
\hline 1983 & 129.4 & 121.2 & 125.6 & 134.0 & 127.5 \\
\hline 1984 & 119.8 & 112.6 & 117.3 & 123.7 & 117.1 \\
\hline 1985 & 119.2 & 112.4 & 116.3 & 123.3 & 116.3 \\
\hline 1986 & 161.1 & 146.8 & 150.2 & 170.9 & 161.0 \\
\hline 1987 & 194.1 & 172.8 & 175.5 & 209.9 & 197.3 \\
\hline 1988 & 204.8 & 180.7 & 191.6 & 218.3 & 205.2 \\
\hline
\end{tabular}




\section{Appendix Table BT}

Price Indexes for Manufactured Exports by Germany, U.S. Dollars, 1963 Weights of OECD Exports to Developing Countries

(Annual Averages, $1975=100$ )

\begin{tabular}{|c|c|c|c|c|c|}
\hline & $\begin{array}{c}\text { All } \\
\text { Manufactures }\end{array}$ & SITC 5 & SITC 6 & SITC 7 & SITC 8 \\
\hline 1953 & 35.2 & 40.6 & 36.8 & 33.6 & 32.6 \\
\hline $\begin{array}{l}1954 \\
1955\end{array}$ & $\begin{array}{l}34.4 \\
34.9\end{array}$ & 40.3 & 35.7 & 32.8 & 32.2 \\
\hline 1956 & 35.4 & 38.6 & 37.5 & 33.9 & $\begin{array}{l}32.4 \\
32.9\end{array}$ \\
\hline 1957 & 36.1 & 39.4 & 38.3 & 34.5 & 33.8 \\
\hline 1958 & 36.4 & 40.7 & 38.3 & 34.8 & 33.9 \\
\hline 1959 & 35.9 & 40.0 & 37.8 & 34.4 & 33.5 \\
\hline 1960 & 36.1 & 39.3 & 38.5 & 34.6 & 33.9 \\
\hline 1961 & 38.1 & 41.1 & 40.2 & 36.7 & 36.3 \\
\hline 1962 & 38.9 & 41.3 & 40.6 & 37.7 & 37.7 \\
\hline 1963 & 39.3 & 42.3 & 40.7 & 38.0 & 38.1 \\
\hline 1964 & 39.7 & 42.1 & 41.7 & 38.3 & 38.8 \\
\hline 1965 & 40.8 & 42.3 & 42.6 & 39.6 & 40.1 \\
\hline 1966 & 41.5 & 42.6 & 43.3 & 40.4 & 41.4 \\
\hline 1967 & 41.4 & 42.7 & 42.3 & 40.6 & 41.9 \\
\hline 1968 & 41.0 & 41.7 & 41.9 & 40.4 & 41.8 \\
\hline 1969 & 42.8 & 41.7 & 43.4 & 42.7 & 43.6 \\
\hline 1970 & 48.5 & 46.4 & 49.5 & 48.6 & 49.1 \\
\hline 1971 & 53.3 & 50.0 & 52.7 & 54.6 & 54.4 \\
\hline 1972 & 60.0 & 55.5 & 58.5 & 61.9 & 62.8 \\
\hline 1973 & 76.4 & 70.3 & 76.3 & 78.0 & 79.3 \\
\hline 1974 & 89.7 & 90.7 & 93.3 & 87.4 & 89.0 \\
\hline 1975 & 100.0 & 100.0 & 100.0 & 100.0 & 100.0 \\
\hline 1976 & 100.8 & 98.7 & 100.0 & 101.9 & 101.0 \\
\hline 1977 & 111.7 & 108.0 & 107.7 & 115.1 & 112.5 \\
\hline 1978 & 130.9 & 124.9 & 125.7 & 135.8 & 132.5 \\
\hline 1979 & 151.6 & 142.2 & 145.7 & 158.6 & 150.0 \\
\hline 1980 & 162.5 & 155.7 & 155.9 & 168.9 & 163.1 \\
\hline 1981 & 137.8 & 135.1 & 131.9 & 142.7 & 136.8 \\
\hline 1982 & 134.6 & 128.1 & 130.3 & 139.8 & 133.1 \\
\hline 1983 & 129.6 & 121.2 & 122.9 & 136.6 & 129.8 \\
\hline 1984 & 119.9 & 111.3 & 114.5 & 126.0 & 119.7 \\
\hline 1985 & 119.3 & 111.5 & 113.5 & 125.5 & 119.2 \\
\hline 1986 & 162.2 & 148.6 & 148.1 & 174.8 & 165.3 \\
\hline 1987 & 195.9 & 174.3 & 173.6 & 216.2 & 203.0 \\
\hline 1988 & 206.3 & 181.6 & 187.1 & 225.7 & 211.1 \\
\hline
\end{tabular}




\section{$-52-$ \\ Appendix Table BB}

Price Indexes for Manufactured Exports by Germany, U.S. Dollars, 1975 Weights of OECD Exports to Developing Countries

(Annual Averages, 1975=100)

\begin{tabular}{|c|c|c|c|c|c|}
\hline & $\begin{array}{c}\text { A } 11 \\
\text { Manufactures }\end{array}$ & SITC 5 & SITC 6 & SITC 7 & SITC 8 \\
\hline $\begin{array}{l}1953 \\
1954\end{array}$ & $\begin{array}{l}35.7 \\
34.9\end{array}$ & 44.0 & 36.3 & 34.3 & 32.5 \\
\hline 1954 & 34.9 & 43.7 & 35.2 & 33.5 & 32.2 \\
\hline 1955 & 35.4 & 42.8 & 36.5 & 34.0 & 32.4 \\
\hline 1956 & 35.9 & 42.0 & 37.1 & 34.6 & 32.6 \\
\hline 1957 & 36.5 & 42.3 & 37.9 & 35.2 & 33.2 \\
\hline 1958 & 36.9 & 43.2 & 38.1 & 35.6 & 33.3 \\
\hline 1959 & 36.3 & 42.5 & 37.6 & 35.0 & 32.9 \\
\hline 1960 & 36.5 & 41.9 & 38.0 & 35.2 & 33.3 \\
\hline 1961 & 38.4 & 43.5 & 39.5 & 37.2 & 35.7 \\
\hline 1962 & 39.1 & 43.1 & 40.1 & 38.2 & 37.2 \\
\hline 1963 & 39.4 & $43 . \overline{7}$ & 40.1 & 38.4 & 37.7 \\
\hline 1964 & 39.7 & 43.3 & 40.8 & 38.8 & 38.4 \\
\hline 1965 & 40.7 & 43.3 & 41.6 & 39.9 & 39.8 \\
\hline 1966 & 41.3 & 43.3 & 42.0 & 40.8 & 41.0 \\
\hline 1967 & 41.2 & 43.2 & 40.8 & 41.0 & 41.6 \\
\hline 1968 & 40.7 & 41.9 & 40.5 & 40.7 & 41.5 \\
\hline 1969 & 42.6 & 41.8 & 42.5 & 43.0 & 43.2 \\
\hline 1970 & 48.5 & 46.6 & 49.0 & 49.0 & 48.7 \\
\hline 1971 & 53.3 & 50.1 & 51.9 & 54.9 & 54.2 \\
\hline 1972 & 59.7 & 55.3 & 57.3 & 62.0 & 62.4 \\
\hline 1973 & 75.9 & 69.5 & 75.4 & 77.8 & 78.9 \\
\hline 1974 & 89.6 & 92.0 & 93.7 & 87.4 & 89.3 \\
\hline 1975 & 100.0 & 100.0 & 100.0 & 100.0 & 100.0 \\
\hline 1976 & 100.7 & 99.0 & 99.4 & 101.6 & 100.7 \\
\hline 1977 & 111.1 & 108.0 & 104.7 & 114.6 & 111.8 \\
\hline 1978 & 130.5 & 124.6 & 124.2 & 134.5 & 131.6 \\
\hline 1979 & 153.0 & 143.2 & 144.2 & 159.7 & 148.9 \\
\hline 1980 & 163.7 & 157.7 & 153.2 & 169.9 & 162.0 \\
\hline 1981 & 138.6 & 135.8 & 130.2 & 143.6 & 134.6 \\
\hline 1982 & 136.1 & 129.0 & 131.6 & 140.2 & 131.1 \\
\hline 1983 & 130.3 & 123.2 & 120.7 & 136.6 & 128.2 \\
\hline 1984 & 120.9 & 115.1 & 112.9 & 126.3 & 118.2 \\
\hline 1985 & 120.4 & 114.2 & 112.9 & 125.6 & 117.6 \\
\hline 1986 & 161.7 & 147.0 & 143.0 & 174.8 & 163.6 \\
\hline 1987 & 195.0 & 173.3 & 164.9 & 216.2 & 200.9 \\
\hline 1988 & 207.9 & 180.8 & 184.7 & 226.3 & 209.4 \\
\hline
\end{tabular}




\section{Appendix Table B9}

Price Indexes for Manufactured Exports by Japan, U.S. Dollars, 1963 Weights of OECD Exports to the Wor Id

(Annual Averages, 1975=100)

\begin{tabular}{|c|c|c|c|c|c|}
\hline & $\begin{array}{c}\text { All } \\
\text { Manufactures }\end{array}$ & SITC 5 & SITC 6 & SITC 7 & SITC 8 \\
\hline $\begin{array}{l}1953 \\
1954\end{array}$ & $\begin{array}{l}61.0 \\
58.6\end{array}$ & $\begin{array}{l}61.5 \\
61.5\end{array}$ & $\begin{array}{l}54.9 \\
50.7\end{array}$ & $\begin{array}{l}68.4 \\
66.9\end{array}$ & $\begin{array}{l}56.6 \\
55.1\end{array}$ \\
\hline 1955 & 57.5 & 57.8 & 51.2 & 64.7 & 54.3 \\
\hline 1956 & 60.3 & 57.3 & 56.9 & 67.1 & 53.9 \\
\hline 1957 & 61.4 & 56.5 & 56.8 & 69.9 & 53.6 \\
\hline 1958 & 56.6 & 52.5 & 49.2 & 66.2 & 52.9 \\
\hline 1959 & 56.6 & 50.4 & 50.8 & 64.8 & 54.3 \\
\hline 1960 & 56.4 & 50.3 & 50.9 & 63.7 & 56.1 \\
\hline 1961 & 55.3 & 48.3 & 50.2 & 62.5 & 55.5 \\
\hline 1962 & 54.0 & 45.7 & 48.2 & 61.7 & 56.0 \\
\hline 1963 & 53.6 & 44.8 & 48.6 & 60.5 & 56.9 \\
\hline 1964 & 54.2 & 45.9 & 49.5 & 60.4 & 58.0 \\
\hline 1965 & 54.2 & 45.7 & 49.3 & 60.7 & 57.9 \\
\hline 1966 & 54.2 & 43.4 & 49.9 & 61.1 & 57.4 \\
\hline 1967 & 54.6 & 42.4 & 50.8 & 61.4 & 57.8 \\
\hline 1968 & 55.2 & 42.8 & 51.4 & 62.1 & 58.6 \\
\hline 1969 & 56.5 & 43.4 & 53.6 & 62.9 & 59.9 \\
\hline 1970 & 58.1 & 43.0 & 56.1 & 64.3 & 62.2 \\
\hline 1971 & 59.7 & 43.5 & 56.7 & 66.8 & 65.0 \\
\hline $\begin{array}{l}1972 \\
1973\end{array}$ & $\begin{array}{l}65.7 \\
80.7\end{array}$ & $\begin{array}{l}47.0 \\
60.8\end{array}$ & $\begin{array}{l}63.4 \\
83.6\end{array}$ & $\begin{array}{l}73.1 \\
84.3\end{array}$ & $\begin{array}{l}72.3 \\
86.7\end{array}$ \\
\hline 1974 & 99.0 & 92.3 & 106.3 & 96.5 & 97.6 \\
\hline 1975 & 100.0 & 100.0 & 100.0 & 100.0 & 100.0 \\
\hline 1976 & 103.2 & 100.8 & 107.1 & 101.1 & 102.9 \\
\hline 1977 & 111.8 & 105.3 & 116.1 & 110.0 & 113.2 \\
\hline 1978 & 135.8 & 120.0 & 142.1 & 135.1 & 138.0 \\
\hline 1979 & 141.9 & 145.2 & 153.8 & 133.6 & 136.5 \\
\hline 1980 & 151.3 & 167.1 & 171.3 & 136.0 & 141.2 \\
\hline 1981 & 157.2 & 169.8 & 172.3 & 145.1 & 147.3 \\
\hline 1982 & 143.8 & 149.8 & 156.3 & 134.8 & 134.6 \\
\hline 1983 & 145.9 & 150.8 & 157.7 & 137.2 & 137.2 \\
\hline 1984 & 146.6 & 148.7 & 159.4 & 137.8 & 138.8 \\
\hline 1985 & 144.4 & 146.5 & 155.9 & 136.0 & 138.6 \\
\hline 1986 & 181.2 & 178.3 & 189.9 & 173.1 & 184.4 \\
\hline 1987 & 201.9 & 200.0 & 213.1 & 192.0 & 204.0 \\
\hline 1988 & 226.9 & 230.0 & 249.1 & 210.2 & 220.7 \\
\hline
\end{tabular}




\section{Appendix Table B10}

Price Indexes for Manufactured Exports by Japan, U.S. Dollars, 1975 Weights of OECD Exports to the World

(Annual Averages, 1975=100)

\begin{tabular}{|c|c|c|c|c|c|}
\hline & $\begin{array}{c}\text { Al1 } \\
\text { Manufactures }\end{array}$ & SITC 5 & SITC 6 & SITC 7 & SITC 8 \\
\hline $\begin{array}{l}1953 \\
1954\end{array}$ & $\begin{array}{l}62.3 \\
60.1\end{array}$ & $\begin{array}{l}63.7 \\
63.8\end{array}$ & $\begin{array}{l}55.3 \\
51.0\end{array}$ & $\begin{array}{l}69.2 \\
67.6\end{array}$ & $\begin{array}{l}56.7 \\
55.1\end{array}$ \\
\hline 1955 & 58.8 & 59.6 & 51.8 & 65.5 & 54.3 \\
\hline 1956 & 61.7 & 58.9 & 58,3 & 67.7 & 53.9 \\
\hline $\begin{array}{l}1957 \\
1958\end{array}$ & $\begin{array}{l}62.8 \\
58.1\end{array}$ & $\begin{array}{l}58.1 \\
53.8\end{array}$ & $\begin{array}{l}58.6 \\
50.4\end{array}$ & $\begin{array}{l}70.3 \\
66.3\end{array}$ & $\begin{array}{l}53.6 \\
52.9\end{array}$ \\
\hline 1959 & 57.9 & 51.6 & 52.1 & 65.0 & 54.4 \\
\hline 1960 & 57.6 & 51.4 & 52.3 & 63.9 & 56.2 \\
\hline 1961 & 56.3 & 49.0 & 51.4 & 62.5 & 55.5 \\
\hline 1962 & 54.9 & 45.9 & 49.1 & 61.6 & 56.0 \\
\hline 1963 & 54.1 & 44.6 & 49.0 & 60.2 & 56.8 \\
\hline 1964 & 54.5 & 45.7 & 49.9 & 59.9 & 58.0 \\
\hline 1965 & 54.5 & 45.3 & 49.7 & 60.2 & 58.0 \\
\hline 1966 & 54.4 & 42.8 & 50.0 & 60.6 & 57.5 \\
\hline 1967 & 54.7 & 42.0 & 51.1 & 60.8 & 57.8 \\
\hline 1968 & 55.2 & 41.9 & 51.4 & 61.6 & 58.6 \\
\hline 1969 & 56.3 & 42.3 & 53.4 & 62.4 & 60.2 \\
\hline 1970 & 58.0 & 41.8 & 56.2 & 63.9 & 62.8 \\
\hline 1971 & 59.9 & 42.2 & 57.1 & 66.7 & 65.7 \\
\hline 1972 & 65.8 & 45.6 & 63.4 & 73.1 & 72.7 \\
\hline 1973 & 80.2 & 60.2 & 82.7 & 84.1 & 87.6 \\
\hline 1974 & 98.9 & 92.8 & 107.6 & 96.3 & 98.3 \\
\hline 1975 & 100.0 & 100.0 & 100.0 & 100.0 & 100.0 \\
\hline 1976 & 102.6 & 101.6 & 106.2 & 101.0 & 102.5 \\
\hline 1977 & 110.6 & 105.4 & 114.6 & 109.4 & 112.5 \\
\hline $\begin{array}{l}1978 \\
1979\end{array}$ & $\begin{array}{l}134.4 \\
140.3\end{array}$ & $\begin{array}{l}118.5 \\
147.5\end{array}$ & $\begin{array}{l}141.2 \\
153.2\end{array}$ & $\begin{array}{l}134.4 \\
132.3\end{array}$ & $\begin{array}{l}136.6 \\
135.1\end{array}$ \\
\hline 1980 & 149.0 & 169.6 & 170.0 & 134.9 & 140.1 \\
\hline 1981 & 155.8 & 171.8 & 172.9 & 144.4 & 146.0 \\
\hline 1982 & 142.7 & 151.7 & 156.8 & 134.3 & 133.6 \\
\hline 1983 & 144.1 & 152.3 & 156.8 & 136.4 & 135.7 \\
\hline 1984 & 144.6 & 150.0 & 158.5 & 136.8 & 136.8 \\
\hline 1985 & 142.4 & 147.2 & 155.1 & 135.1 & 136.3 \\
\hline 1986 & 177.2 & 173.8 & 186.2 & 171.3 & 178.8 \\
\hline 1987 & 197.3 & 198.3 & 207.6 & 189.9 & 197.0 \\
\hline 1988 & 221.0 & 227.7 & 243.4 & 207.8 & 212.4 \\
\hline
\end{tabular}




\section{Appendix Table B11}

Price Indexes for Manufactured Exports by Japan, U.S. Dollars, 1963 Weights of OECD Exports to Developing Countries (Annual Averages, 1975=100)

\begin{tabular}{|c|c|c|c|c|c|}
\hline & $\begin{array}{c}\text { Al1 } 1 \\
\text { Manufactures }\end{array}$ & SITC 5 & SITC 6 & SITC 7 & SITC 8 \\
\hline $\begin{array}{l}1953 \\
1954\end{array}$ & $\begin{array}{l}60.7 \\
58.5\end{array}$ & $\begin{array}{l}62.8 \\
61.9\end{array}$ & 55.1 & 65.8 & 56.8 \\
\hline 1955 & 57.3 & 58.5 & 51.6 & $\begin{array}{l}64.3 \\
62.4\end{array}$ & $\begin{array}{l}55.2 \\
54.5\end{array}$ \\
\hline 1956 & 60.2 & 58.0 & 56.9 & 65.1 & 54.4 \\
\hline $\begin{array}{l}1957 \\
1958\end{array}$ & $\begin{array}{l}61.6 \\
57.3\end{array}$ & $\begin{array}{l}57.5 \\
53.9\end{array}$ & $\begin{array}{l}57.3 \\
50.1\end{array}$ & $\begin{array}{l}68.3 \\
65.0\end{array}$ & $\begin{array}{l}54.2 \\
53.2\end{array}$ \\
\hline 1959 & 57.1 & 51.8 & 51.6 & 63.7 & 54.7 \\
\hline 1960 & 56.9 & 51.6 & 51.8 & 62.9 & 56.3 \\
\hline 1961 & 55.9 & 49.7 & 51.1 & 61.9 & 55.6 \\
\hline 1962 & 54.7 & 47.7 & 49.0 & 61.2 & 56.3 \\
\hline 1963 & 54.3 & 46.9 & 49.2 & 60.2 & 57.2 \\
\hline 1964 & 54.8 & 48.1 & 50.0 & 60.1 & 58.5 \\
\hline 1965 & 54.9 & 48.3 & 49.7 & 60.4 & 58.4 \\
\hline 1966 & 54.7 & 46.1 & 49.8 & 60.8 & 57.7 \\
\hline 1967 & 55.0 & 45.1 & 50.8 & 61.1 & 58.1 \\
\hline 1968 & 55.5 & 45.3 & 51.2 & 61.8 & 58.8 \\
\hline 1969 & 56.7 & 45.8 & 53.2 & 62.6 & 60.2 \\
\hline 1970 & 58.2 & 45.3 & 55.6 & 63.9 & .62 .6 \\
\hline 1971 & 60.0 & 46.2 & 56.7 & 66.3 & 65.3 \\
\hline 1972 & 66.0 & 50.2 & 63.5 & 72.5 & 72.6 \\
\hline 1973 & 80.5 & 63.3 & 82.8 & 84.1 & 87.2 \\
\hline 1974 & 98.0 & 91.0 & 104.7 & 96.4 & 97.5 \\
\hline 1975 & 100.0 & 100.0 & 100.0 & 100.0 & 100.0 \\
\hline 1976 & 102.8 & 99.9 & 106.4 & 101.3 & 103.1 \\
\hline 1977 & 111.2 & 105.6 & 114.6 & 110.3 & 113.5 \\
\hline 1978 & 135.7 & 124.3 & 140.4 & 135.5 & 138.8 \\
\hline 1979 & 140.2 & 142.1 & 150.1 & 134.0 & 136.3 \\
\hline 1980 & 148.9 & 160.5 & 165.8 & 136.7 & 141.9 \\
\hline 1981 & 156.0 & 165.3 & 169.6 & 146.2 & 147.2 \\
\hline 1982 & 142.9 & 145.1 & 155.2 & 135.7 & 134.2 \\
\hline 1983 & 146.6 & 146.0 & 155.5 & 138.1 & 137.3 \\
\hline 1984 & 145.0 & 144.3 & 157.4 & 138.3 & 138.7 \\
\hline 1985 & 143.4 & 142.8 & 154.7 & 137.0 & 138.7 \\
\hline 1986 & 181.3 & 180.1 & 188.6 & 175.4 & 184.6 \\
\hline 1987 & 201.1 & 200.6 & 208.7 & 194.5 & 205.5 \\
\hline 1988 & 225.8 & 227.9 & 243.2 & 213.9 & 224.0 \\
\hline
\end{tabular}


Appendix Table B12

Price Indexes for Manufactured Exports by Japan, U.S. Dollars, 1975 Weights of OECD Exports to Developing Countries

(Annual Averages, $1975=100$ )

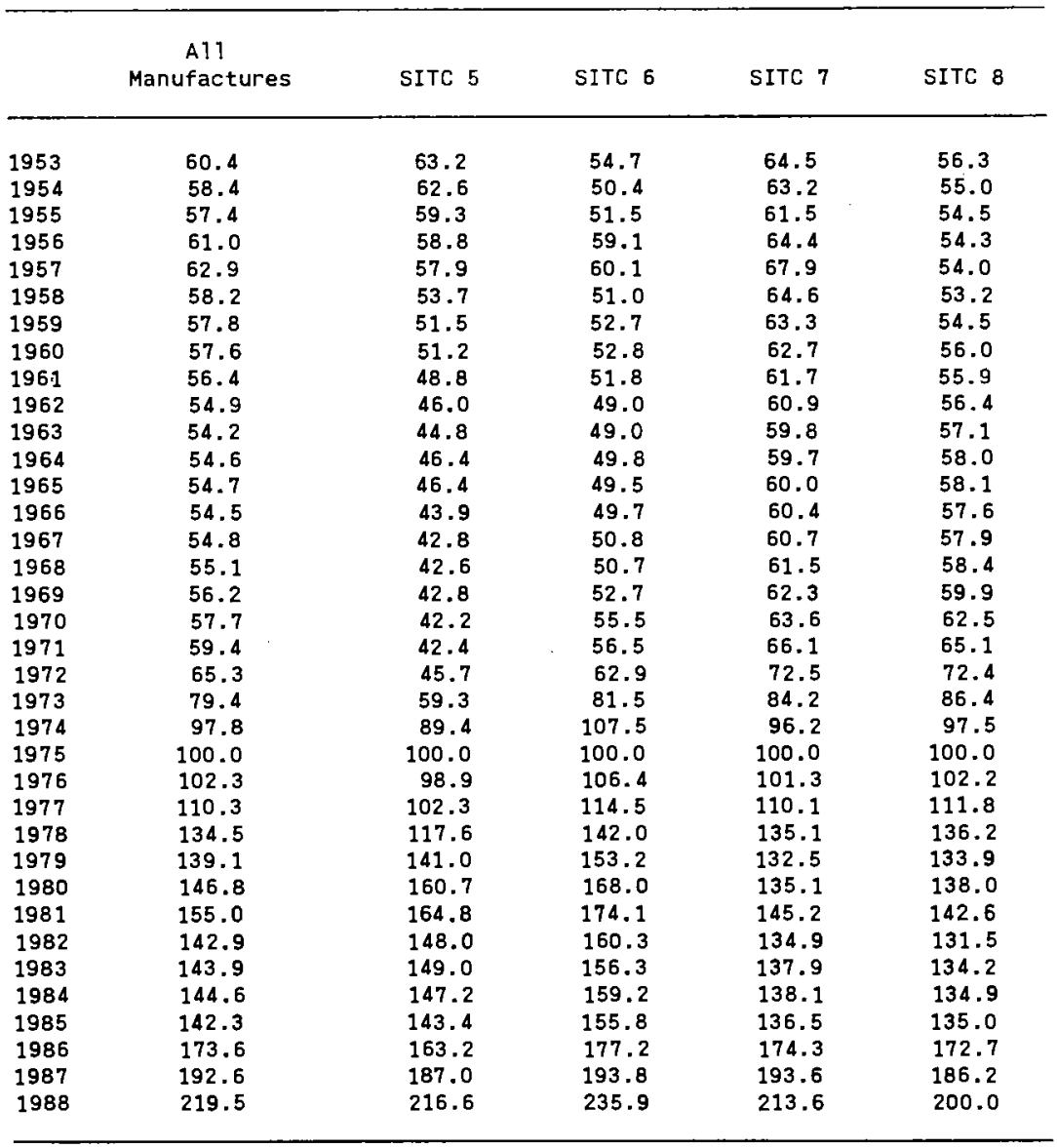


Appendix Table B13

Price Indexes for Manufactured Exports by the U.S., U.S. Dollars, 1963 Weights of OECD Exports to the Wor ld

(Annual Averages, 1975=100)

\begin{tabular}{|c|c|c|c|c|c|}
\hline & $\begin{array}{c}\text { A11 } \\
\text { Manufactures }\end{array}$ & SITC 5 & SITC 6 & SITC 7 & SITC 8 \\
\hline 1953 & 51.5 & 61.4 & 47.0 & 51.3 & 57.7 \\
\hline 1954 & 52.0 & 62.9 & 47.1 & 52.0 & 57.7 \\
\hline 1955 & 53.3 & 62.1 & 49.5 & 53.1 & 58.1 \\
\hline 1956 & 55.6 & 60.8 & 51.9 & 56.1 & 59.8 \\
\hline 1957 & 57.8 & 62.5 & 53.8 & 58.9 & 60.8 \\
\hline 1958 & 58.2 & 61.7 & 53.6 & 60.2 & 61.6 \\
\hline 1959 & 59.1 & 60.9 & 54.7 & 61.3 & 61.7 \\
\hline 1960 & 59.4 & 61.6 & 55.2 & 61.4 & 62.2 \\
\hline 1961 & 59.1 & 61.8 & 54.7 & 61.1 & 62.2 \\
\hline 1962 & 58.9 & 60.3 & 54.7 & 61.0 & 62.4 \\
\hline 1963 & 59.0 & 59.5 & 54.7 & 61.4 & 62.6 \\
\hline 1964 & 59.3 & 58.7 & 55.5 & 61.9 & 62.5 \\
\hline 1965 & 60.1 & 59.1 & 56.5 & 62.5 & 63.1 \\
\hline 1966 & 61.1 & 59.5 & 57.7 & 63.5 & 65.0 \\
\hline 1967 & 62.4 & 60.1 & 57.9 & 65.5 & 67.5 \\
\hline 1968 & 63.9 & 59.3 & 59.7 & 67.2 & 70.7 \\
\hline 1969 & 65.7 & 58.5 & 62.2 & 69.0 & 73.3 \\
\hline 1970 & 68.1 & 59.9 & 64.9 & 71.7 & 74.7 \\
\hline 1971 & 70.5 & 60.3 & 66.8 & 75.3 & 76.0 \\
\hline 1972 & 72.4 & 60.5 & 69.7 & 77.2 & 77.4 \\
\hline 1973 & 76.0 & 62.3 & 75.6 & 79.4 & 81.2 \\
\hline 1974 & 89.2 & 79.7 & 92.5 & 88.9 & 92.9 \\
\hline 1975 & 100.0 & 100.0 & 100.0 & 100.0 & 100.0 \\
\hline 1976 & 105.4 & 104.4 & 106.0 & 105.6 & 104.3 \\
\hline 1977 & 111.8 & 108.6 & 113.5 & 111.9 & 110.3 \\
\hline 1978 & 119.5 & 111.8 & 121.8 & 120.9 & 116.2 \\
\hline 1979 & 132.3 & 132.5 & 136.2 & 130.6 & 127.9 \\
\hline 1980 & 146.8 & 152.3 & 149.5 & 144.3 & 142.6 \\
\hline 1981 & 161.7 & 166.3 & 164.9 & 158.1 & 162.2 \\
\hline 1982 & 168.5 & 173.1 & 165.2 & 168.9 & 170.3 \\
\hline 1983 & 171.2 & 172.4 & 164.7 & 173.7 & 176.3 \\
\hline 1984 & 176.2 & 177.4 & 170.3 & 178.6 & 179.6 \\
\hline 1985 & 177.6 & 177.4 & 168.0 & 182.4 & 183.8 \\
\hline 1986 & 179.3 & 177.2 & 167.4 & 185.6 & 188.3 \\
\hline 1987 & 185.3 & 185.8 & 175.7 & 189.5 & 191.7 \\
\hline 1988 & 197.5 & 209.9 & 193.7 & 195.2 & 199.4 \\
\hline
\end{tabular}


Appendix Table B14

Price Indexes for Manufactured Exports by the U.S., U.S. Dollars, 1975 Weights of OECD Exports to the Wor 1d

(Annual Averages, 1975=100)

\begin{tabular}{|c|c|c|c|c|c|}
\hline & $\begin{array}{c}\text { A11 } \\
\text { Manufactures }\end{array}$ & SITC 5 & SITC 6 & SITC 7 & SITC 8 \\
\hline $\begin{array}{l}1953 \\
1954\end{array}$ & $\begin{array}{l}52.3 \\
53.0\end{array}$ & $\begin{array}{l}65.5 \\
67.0\end{array}$ & $\begin{array}{l}45.9 \\
46.4\end{array}$ & $\begin{array}{l}52.3 \\
52.9\end{array}$ & $\begin{array}{l}58.3 \\
58.3\end{array}$ \\
\hline 1955 & 54.1 & 65.9 & 48.6 & 54.1 & 58.5 \\
\hline $\begin{array}{l}1956 \\
1957\end{array}$ & $\begin{array}{l}56.4 \\
58.8\end{array}$ & $\begin{array}{l}64.5 \\
66.4\end{array}$ & $\begin{array}{l}51.0 \\
53.3\end{array}$ & $\begin{array}{l}57.1 \\
59.9\end{array}$ & 60.0 \\
\hline $\begin{array}{l}1958 \\
1959\end{array}$ & $\begin{array}{l}59.5 \\
60.3\end{array}$ & $\begin{array}{l}65.2 \\
64.0\end{array}$ & $\begin{array}{l}53.6 \\
54.6\end{array}$ & $\begin{array}{l}61.2 \\
62.4\end{array}$ & $\begin{array}{l}62.0 \\
62.4\end{array}$ \\
\hline $\begin{array}{l}1960 \\
1961\end{array}$ & $\begin{array}{l}60.5 \\
60.1\end{array}$ & $\begin{array}{l}64.7 \\
64.6\end{array}$ & $\begin{array}{l}54.8 \\
54.2\end{array}$ & $\begin{array}{l}62.5 \\
62.0\end{array}$ & $\begin{array}{l}62.9 \\
62.9\end{array}$ \\
\hline 1962 & 59.8 & 63.1 & 54.1 & 61.8 & 62.9 \\
\hline 1963 & 59.8 & 61.8 & 54.1 & 62.0 & 63.0 \\
\hline 1964 & 60.0 & 60.4 & 54.6 & 62.5 & 62.9 \\
\hline 1965 & 60.5 & 60.6 & 55.4 & 63.0 & 63.5 \\
\hline 1966 & 61.5 & 61.1 & 56.3 & 64.1 & 65.4 \\
\hline $\begin{array}{l}1967 \\
1968\end{array}$ & $\begin{array}{l}62.9 \\
64.5\end{array}$ & $\begin{array}{l}61.7 \\
60.7\end{array}$ & $\begin{array}{l}56.7 \\
58.6\end{array}$ & $\begin{array}{l}66.0 \\
67.8\end{array}$ & $\begin{array}{l}68.1 \\
71.0\end{array}$ \\
\hline $\begin{array}{l}1969 \\
1970\end{array}$ & $\begin{array}{l}66.2 \\
68.5\end{array}$ & $\begin{array}{l}59.8 \\
61.0\end{array}$ & $\begin{array}{l}60.8 \\
63.6\end{array}$ & $\begin{array}{l}69.7 \\
72.3\end{array}$ & $\begin{array}{l}73.6 \\
75.0\end{array}$ \\
\hline $\begin{array}{l}1971 \\
1972\end{array}$ & $\begin{array}{l}71.1 \\
72.7\end{array}$ & $\begin{array}{l}61.3 \\
61.2\end{array}$ & $\begin{array}{l}66.0 \\
68.7\end{array}$ & $\begin{array}{l}76.0 \\
77.6\end{array}$ & $\begin{array}{l}76.3 \\
77.6\end{array}$ \\
\hline $\begin{array}{l}1973 \\
1974\end{array}$ & $\begin{array}{l}75.6 \\
88.6\end{array}$ & $\begin{array}{l}62.7 \\
79.7\end{array}$ & $\begin{array}{l}73.3 \\
90.5\end{array}$ & $\begin{array}{l}79.6 \\
89.2\end{array}$ & $\begin{array}{l}81.2 \\
92.9\end{array}$ \\
\hline $\begin{array}{l}1975 \\
1976\end{array}$ & $\begin{array}{l}100.0 \\
105.3\end{array}$ & $\begin{array}{l}100.0 \\
104.6\end{array}$ & $\begin{array}{l}100.0 \\
105.7\end{array}$ & $\begin{array}{l}100.0 \\
105.4\end{array}$ & $\begin{array}{l}100.0 \\
104.4\end{array}$ \\
\hline 1977 & 111.4 & 108.5 & 113.1 & 111.4 & 110.2 \\
\hline 1978 & 119.2 & 111.5 & 122.3 & 120.2 & 116.0 \\
\hline 1979 & 131.6 & 133.9 & 136.4 & 129.3 & 127.1 \\
\hline 1980 & 145.8 & 152.8 & 149.8 & 142.8 & 141.5 \\
\hline 1981 & 160.7 & 166.9 & 166.0 & 156.5 & 159.3 \\
\hline 1982 & 168.3 & 172.9 & 168.3 & 162.0 & 167.4 \\
\hline 1983 & 170.8 & 172.4 & 167.0 & 171.8 & 172.4 \\
\hline 1984 & 175.4 & 176.2 & 172.4 & 176.5 & 175.2 \\
\hline 1985 & 176.8 & 174.9 & 169.9 & 180.2 & 178.5 \\
\hline 1986 & 178.6 & 174.1 & 168.5 & 183.2 & 183.4 \\
\hline 1987 & 183.9 & 184.5 & 176.0 & 186.9 & 186.5 \\
\hline 1988 & 195.1 & 208.3 & 193.2 & 192.3 & 193.4 \\
\hline
\end{tabular}


Appendix Table B15

Price Indexes for Manufactured Exports by the U.S., U.S. Dollars, 1963 Weights of OECD Exports to Developing Countries

(Annual Averages, 1975=100)

\begin{tabular}{|c|c|c|c|c|c|}
\hline & $\begin{array}{c}\text { All } \\
\text { Manufactures }\end{array}$ & SITC 5 & SITC 6 & SITC 7 & SITC 8 \\
\hline $\begin{array}{l}1953 \\
1954\end{array}$ & $\begin{array}{l}51.2 \\
51.8\end{array}$ & $\begin{array}{l}61.6 \\
63.3\end{array}$ & $\begin{array}{l}47.6 \\
47.9\end{array}$ & $\begin{array}{l}49.8 \\
50.2\end{array}$ & $\begin{array}{l}59.2 \\
59.3\end{array}$ \\
\hline $\begin{array}{l}1955 \\
1956\end{array}$ & $\begin{array}{l}53.0 \\
55.2\end{array}$ & $\begin{array}{l}62.4 \\
60.8\end{array}$ & $\begin{array}{l}50.1 \\
52.6\end{array}$ & $\begin{array}{l}51.4 \\
54.5\end{array}$ & $\begin{array}{l}59.8 \\
61.4\end{array}$ \\
\hline $\begin{array}{l}1957 \\
1958\end{array}$ & $\begin{array}{l}57.6 \\
58.4\end{array}$ & $\begin{array}{l}62.9 \\
62.7\end{array}$ & $\begin{array}{l}54.5 \\
54.7\end{array}$ & $\begin{array}{l}57.5 \\
58.9\end{array}$ & $\begin{array}{l}62.4 \\
62.9\end{array}$ \\
\hline 1959 & 59.2 & 62.1 & 55.8 & 60.0 & 63.0 \\
\hline 1960 & 59.4 & 62.8 & 56.3 & 59.9 & 63.5 \\
\hline 1961 & 59.2 & 63.0 & 55.7 & 59.7 & 63.5 \\
\hline 1962 & 59.0 & 61.9 & 55.7 & 59.5 & 63.6 \\
\hline 1963 & 59.0 & 61.1 & 55.6 & 59.9 & 63.5 \\
\hline 1964 & 59.3 & 60.4 & 56.2 & 60.3 & 63.4 \\
\hline $\begin{array}{l}1965 \\
1966\end{array}$ & $\begin{array}{l}60.0 \\
61.0\end{array}$ & $\begin{array}{l}61.0 \\
61.7\end{array}$ & $\begin{array}{l}57.1 \\
58.0\end{array}$ & $\begin{array}{l}60.9 \\
62.2\end{array}$ & $\begin{array}{l}64.0 \\
65.8\end{array}$ \\
\hline 1967 & 62.3 & 62.3 & 58.2 & 64.1 & 68.3 \\
\hline 1968 & 63.8 & 61.8 & 60.1 & 65.8 & 71.2 \\
\hline 1969 & 65.4 & 61.0 & 62.1 & 67.6 & 73.9 \\
\hline 1970 & 67.8 & 62.2 & 64.4 & 70.6 & 75.1 \\
\hline 1971 & 70.4 & 62.9 & 66.7 & 74.2 & 76.4 \\
\hline 1972 & 72.3 & 63.1 & 69.8 & 76.1 & 77.9 \\
\hline 1973 & 75.6 & 64.8 & 74.9 & 78.5 & 81.9 \\
\hline 1974 & 88.6 & 80.3 & 92.1 & 88.3 & 92.9 \\
\hline $\begin{array}{l}1975 \\
1976\end{array}$ & $\begin{array}{l}100.0 \\
105.5\end{array}$ & $\begin{array}{l}100.0 \\
104.4\end{array}$ & $\begin{array}{l}100.0 \\
105.7\end{array}$ & $\begin{array}{l}100.0 \\
105.9\end{array}$ & $\begin{array}{l}100.0 \\
104.6\end{array}$ \\
\hline 1977 & 112.1 & 108.9 & 113.4 & 112.7 & 110.5 \\
\hline 1978 & 120.1 & 113.8 & 121.7 & 121.8 & 116.0 \\
\hline 1979 & 132.5 & 131.3 & 134.7 & 132.3 & 127.7 \\
\hline 1980 & 147.5 & 149.3 & 149.4 & 146.6 & 143.3 \\
\hline 1981 & 162.8 & 164.8 & 164.5 & 160.9 & 164.8 \\
\hline 1982 & 170.6 & 173.2 & 167.3 & 171.8 & 171.6 \\
\hline 1983 & 173.0 & 173.7 & 165.8 & 176.5 & 177.0 \\
\hline 1984 & 177.7 & 178.1 & 171.3 & 181.1 & 180.2 \\
\hline 1985 & 179.6 & 180.9 & 169.5 & 184.7 & 184.6 \\
\hline 1986 & 181.2 & 181.3 & 168.4 & 187.8 & 189.4 \\
\hline 1987 & 185.8 & 187.3 & 174.4 & 191.0 & 193.1 \\
\hline 1988 & 196.6 & 206.4 & 189.8 & 196.9 & 201.1 \\
\hline
\end{tabular}


Appendix Table $B 16$

Price Indexes for Manufactured Exports by the U.S., U.S. Dollars, 1975 Weights of OECD Exports to Developing Countries

(Annual Averages, 1975=100)

\begin{tabular}{|c|c|c|c|c|c|}
\hline & $\begin{array}{c}\text { All } \\
\text { Manufactures }\end{array}$ & SITC 5 & SITC 6 & SITC 7 & SITC 8 \\
\hline 1953 & 50.7 & 62.7 & 44.7 & 50.7 & 57.1 \\
\hline 1954 & 51.4 & 64.2 & 45.6 & 51.2 & 57.2 \\
\hline 1955 & 52.5 & 63.4 & 47.7 & 52.3 & 57.7 \\
\hline 1956 & 54.9 & 61.6 & 50.3 & 55.4 & 59.2 \\
\hline 1957 & 57.4 & 63.4 & 52.9 & 58.3 & 60.3 \\
\hline 1958 & 58.3 & 62.8 & 53.5 & 59.7 & 61.1 \\
\hline 1959 & 59.1 & 62.0 & 54.4 & 60.9 & 61.2 \\
\hline 1960 & 59.3 & 62.8 & 54.6 & 60.8 & 61.7 \\
\hline 1961 & 58.9 & 62.8 & 54.0 & 60.5 & 61.7 \\
\hline 1962 & 58.5 & 61.5 & 53.8 & 60.1 & 61.8 \\
\hline 1963 & 58.5 & 60.3 & 53.8 & 60.4 & 61.8 \\
\hline 1964 & 58.8 & 59.3 & 54.2 & 60.8 & 61.6 \\
\hline 1965 & 59.4 & 59.7 & 54.8 & 61.5 & 62.2 \\
\hline 1966 & 60.4 & 60.3 & 55.5 & 62.7 & 64.0 \\
\hline 1967 & 61.8 & 61.0 & 55.9 & 64.6 & 66.9 \\
\hline 1968 & 63.3 & 60.1 & 57.5 & 66.5 & 70.1 \\
\hline 1969 & 64.9 & 58.9 & 59.7 & 68.5 & 73.0 \\
\hline 1970 & 67.3 & 59.9 & 62.3 & 71.1 & 74.0 \\
\hline 1971 & 70.0 & 60.4 & 65.1 & 74.5 & 75.1 \\
\hline 1972 & 71.7 & 60.3 & 68.0 & 76.1 & 76.3 \\
\hline 1973 & 74.6 & 62.0 & 72.2 & 78.7 & 80.1 \\
\hline 1974 & 87.6 & 78.8 & 89.1 & 88.8 & 92.2 \\
\hline 1975 & 100.0 & 100.0 & 100.0 & 100.0 & 100.0 \\
\hline 1976 & 105.3 & 103.1 & 105.7 & 105.8 & 104.0 \\
\hline 1977 & 111.7 & 107.3 & 113.3 & 112.4 & 109.4 \\
\hline 1978 & 119.9 & 111.3 & 122.9 & 121.1 & 115.1 \\
\hline 1979 & 132.0 & 130.4 & 135.7 & 131.2 & 127.0 \\
\hline 1980 & 146.6 & 148.6 & 149.4 & 145.3 & 141.8 \\
\hline 1981 & 162.0 & 163.4 & 165.3 & 159.7 & 164.4 \\
\hline 1982 & 168.2 & 169.1 & 169.6 & 170.4 & 173.4 \\
\hline 1983 & 169.3 & 168.3 & 163.5 & 175.3 & 179.5 \\
\hline 1984 & 173.9 & 170.5 & 168.4 & 180.4 & 183.1 \\
\hline 1985 & $17,6.0$ & 171.8 & 166.4 & 184.8 & 186.9 \\
\hline 1986 & 177.4 & 174.1 & 162.4 & 188.5 & 193.3 \\
\hline 1987 & 182.4 & 185.2 & 168.7 & 192.2 & 197.8 \\
\hline 1988 & 195.0 & 206.3 & 186.3 & 199.3 & 206.3 \\
\hline
\end{tabular}




\section{Appendix Table B17}

Price Indexes for Manufactured Exports by the U.S., With Quality Corrections for SITC 7 Using Hedonic Price Indexes, U.S. Dollars, 1963 and 1975 Weights of OECD Exports to the World (Annual Averages, 1975=100)

\begin{tabular}{|c|c|c|c|c|}
\hline & \multicolumn{2}{|c|}{1963 Weights } & \multicolumn{2}{|c|}{1975 Weights } \\
\hline & Manufactures & SITC 7 & Manufactures & SITC 7 \\
\hline $\begin{array}{l}1953 \\
1954\end{array}$ & $\begin{array}{l}59.5 \\
59.6\end{array}$ & $\begin{array}{l}71.1 \\
70.7\end{array}$ & $\begin{array}{l}59.9 \\
60.1\end{array}$ & $\begin{array}{l}68.5 \\
68.2\end{array}$ \\
\hline 1955 & 60.8 & 71.3 & 61.2 & 69.2 \\
\hline 1956 & 62.7 & 73.8 & 63.1 & 71.7 \\
\hline 1957 & 64.7 & 76.1 & 65.3 & 74.0 \\
\hline 1958 & 64.0 & 74.6 & 64.7 & 72.7 \\
\hline 1959 & 64.0 & 73.8 & 64.8 & 72.3 \\
\hline 1960 & 63.7 & 72.2 & 64.4 & 71.1 \\
\hline 1961 & 63.2 & 71.3 & 63.9 & 70.3 \\
\hline 1962 & 63.0 & 71.2 & 63.6 & 70.2 \\
\hline 1963 & 62.7 & 70.7 & 63.2 & 69.6 \\
\hline 1964 & 62.7 & 70.3 & 63.0 & 69.3 \\
\hline 1965 & 62.8 & 69.2 & 63.0 & 68.6 \\
\hline $\begin{array}{l}1966 \\
1967\end{array}$ & $\begin{array}{l}63.3 \\
64.1\end{array}$ & $\begin{array}{l}68.6 \\
69.6\end{array}$ & $\begin{array}{l}63.5 \\
64.5\end{array}$ & $\begin{array}{l}68.5 \\
69.5\end{array}$ \\
\hline $\begin{array}{l}1968 \\
1969\end{array}$ & $\begin{array}{l}65.3 \\
66.8\end{array}$ & $\begin{array}{l}70.5 \\
71.6\end{array}$ & $\begin{array}{l}65.8 \\
67.1\end{array}$ & $\begin{array}{l}70.7 \\
71.8\end{array}$ \\
\hline $\begin{array}{l}1970 \\
1971\end{array}$ & $\begin{array}{l}69.3 \\
71.2\end{array}$ & $\begin{array}{l}74.5 \\
77.1\end{array}$ & $\begin{array}{l}69.6 \\
71.8\end{array}$ & $\begin{array}{l}74.7 \\
77.7\end{array}$ \\
\hline $\begin{array}{l}1972 \\
1973\end{array}$ & $\begin{array}{l}72.9 \\
76.3\end{array}$ & $\begin{array}{l}78.5 \\
80.2\end{array}$ & $\begin{array}{l}73.3 \\
75.8\end{array}$ & $\begin{array}{l}78.8 \\
80.2\end{array}$ \\
\hline 1974 & 88.7 & B7.7 & 87.9 & 67.9 \\
\hline 1975 & 100.0 & 100.0 & 100.0 & 100.0 \\
\hline $\begin{array}{l}1976 \\
1977\end{array}$ & $\begin{array}{l}105.4 \\
110.9\end{array}$ & $\begin{array}{l}105.5 \\
109.7\end{array}$ & $\begin{array}{l}105.3 \\
110.3\end{array}$ & $\begin{array}{l}105.5 \\
109.3\end{array}$ \\
\hline 1978 & 117.9 & 117.2 & 117.6 & 116.9 \\
\hline 1979 & 128.7 & 122.7 & 128.0 & 122.2 \\
\hline 1980 & 144.3 & 138.8 & 143.0 & 137.2 \\
\hline 1981 & 158.8 & 151.6 & 157.3 & 149.8 \\
\hline 1982 & 165.5 & 162.1 & 165.0 & 160.4 \\
\hline 1983 & 166.9 & 164.2 & 166.6 & 163.1 \\
\hline 1984 & 171.5 & 168.3 & 170.7 & 167.0 \\
\hline 1985 & 172.5 & 171.0 & 171.8 & 170.2 \\
\hline 1986 & 174.2 & 174.2 & 173.5 & 173.3 \\
\hline $\begin{array}{l}1987 \\
1988\end{array}$ & $\begin{array}{l}179.4 \\
190.9\end{array}$ & $\begin{array}{l}176.9 \\
181.3\end{array}$ & $\begin{array}{l}178.5 \\
189.2\end{array}$ & $\begin{array}{l}176.3 \\
180.8\end{array}$ \\
\hline
\end{tabular}


 \\ Appendix Table B18}

Price Indexes for Manufactured Exports by the U.S.,

With Quality Corrections for SITC 7 Using Hedonic Price Indexes,

U.S. Dollars, 1963 and 1975 Weights of OECD Exports to Developing Countries

(Annual Averages, 1975=100)

\begin{tabular}{|c|c|c|c|c|}
\hline & \multicolumn{2}{|c|}{1963 Weights } & \multicolumn{2}{|c|}{1975 Weights } \\
\hline & $\begin{array}{c}\mathrm{A} 11 \\
\text { Manufactures }\end{array}$ & SITC 7 & $\begin{array}{c}\text { All } \\
\text { Manufactures }\end{array}$ & SITC 7 \\
\hline $\begin{array}{l}1953 \\
1954\end{array}$ & $\begin{array}{l}58.0 \\
58.2\end{array}$ & $\begin{array}{l}64.5 \\
64.4\end{array}$ & $\begin{array}{l}57.6 \\
58.2\end{array}$ & $\begin{array}{l}64.8 \\
64.8\end{array}$ \\
\hline 1955 & 59.1 & 64.7 & 59.0 & 65.3 \\
\hline 1956 & 61.0 & 67.2 & 61.2 & 68.2 \\
\hline 1957 & 63.2 & 70.0 & 63.6 & 70.7 \\
\hline 1958 & 63.1 & 69.4 & 63.6 & 70.4 \\
\hline 1959 & 63.2 & 69.2 & 63.5 & 69.9 \\
\hline 1960 & 63.0 & 67.8 & 63.0 & 68.4 \\
\hline 1961 & 62.5 & 67.2 & 62.4 & 67.6 \\
\hline 1962 & 62.4 & 67.1 & 62.1 & 67.4 \\
\hline 1963 & 62.0 & 66.5 & 61.6 & 66.7 \\
\hline 1964 & 62.0 & 66.4 & 61.5 & 66.6 \\
\hline 1965 & 61.7 & 65.0 & 61.3 & 65.7 \\
\hline 1966 & 62.2 & 64.8 & 61.8 & 65.9 \\
\hline 1967 & 63.1 & 66.0 & 62.7 & 66.9 \\
\hline 1968 & 64.4 & 67.1 & 64.0 & 68.2 \\
\hline 1969 & 65.9 & 68.9 & 65.4 & 69.9 \\
\hline 1970 & 68.4 & 72.1 & 67.8 & 72.7 \\
\hline 1971 & 70.6 & 74.8 & 70.1 & 75.3 \\
\hline 1972 & 72.4 & 76.4 & 71.6 & 76.6 \\
\hline 1973 & 75.7 & 78.9 & 74.4 & 78.7 \\
\hline 1974 & 88.2 & 87.5 & 87.1 & 87.8 \\
\hline 1975 & 100.0 & 100.0 & 100.0 & 100.0 \\
\hline 1976 & 105.6 & 106.0 & 105.2 & 105.6 \\
\hline 1977 & 111.4 & 111.0 & 110.8 & 110.6 \\
\hline 1978 & 118.7 & 118.8 & 118.4 & 118.2 \\
\hline 1979 & 129.2 & 125.5 & 128.8 & 125.0 \\
\hline 1980 & 147.2 & 145.8 & 145.0 & 142.1 \\
\hline 1981 & 162.2 & 159.3 & 159.8 & 155.4 \\
\hline 1982 & 170.3 & 170.8 & 168.1 & 166.1 \\
\hline 1983 & 171.6 & 173.3 & 168.1 & 168.9 \\
\hline 1984 & 176.1 & 177.5 & 172.4 & 173.4 \\
\hline 1985 & 177.9 & 180.8 & 174.3 & 177.3 \\
\hline 1986 & 179.6 & 183.8 & 175.9 & 181.2 \\
\hline 1987 & 183.8 & 186.5 & 181.2 & 184.6 \\
\hline 1988 & 194.3 & 191.8 & 193.0 & 191.1 \\
\hline
\end{tabular}




\section{Notes to Appendix Tables B17 and B18}

The hedonic price indexes for the commodities listed below were substituted for the conventional U.S. export or domestic price series used for the indexes covering SITC 7 , and A11 Manufactures in Tables B13 through B16. The hedonic indexes were also inserted in a few cases for which no conventional price indexes had been available, so that the commodity coverage in Tables 817 and $\mathrm{B} 18$ is slightly higher than in the earlier tables.



*With whee 1 tractors weighted $1 / 6$ and crawler tractors $5 / 6$ in accordance with U.S. export weights. 
 \\ Appendix Table B19}

Price Indexes for Manufactured Exports by Developed Countries, with Quality Corrections for SITC 7 Using Hedonic Prices Indexes, U.S. Dollars, 1975 Weights of OECD Exports to the World (Annual Averages, $1975=100$ )

\begin{tabular}{|c|c|c|c|c|}
\hline & \multicolumn{2}{|c|}{ A11 Manufactures } & \multicolumn{2}{|c|}{ SITC 7} \\
\hline & $\begin{array}{l}\text { Adjusted for } \\
\text { U.s. Only }\end{array}$ & $\begin{array}{l}\text { Adjusted for } \\
\text { A11 Countries }\end{array}$ & $\begin{array}{l}\text { Adjusted for } \\
\text { U.s. Only }\end{array}$ & $\begin{array}{l}\text { Adjusted far } \\
\text { A11 Countries }\end{array}$ \\
\hline $\begin{array}{l}1953 \\
1954\end{array}$ & $\begin{array}{l}51.0 \\
50.4\end{array}$ & $\begin{array}{l}57.6 \\
56.7\end{array}$ & $\begin{array}{l}53.5 \\
52.8\end{array}$ & $\begin{array}{l}67.2 \\
66.1\end{array}$ \\
\hline $\begin{array}{l}1955 \\
1956\end{array}$ & $\begin{array}{l}50.7 \\
52.0\end{array}$ & $\begin{array}{l}57.0 \\
58.3\end{array}$ & $\begin{array}{l}53.0 \\
54.4\end{array}$ & $\begin{array}{l}66.2 \\
67.7\end{array}$ \\
\hline 1957 & 53.1 & 59.4 & 56.0 & 69.2 \\
\hline $\begin{array}{l}1958 \\
1959\end{array}$ & $\begin{array}{l}52.2 \\
51.7\end{array}$ & $\begin{array}{l}57.7 \\
56.9\end{array}$ & $\begin{array}{l}55.3 \\
54.6\end{array}$ & $\begin{array}{l}66.9 \\
65.4\end{array}$ \\
\hline 1960 & 51.6 & 56.3 & 54.1 & 64.0 \\
\hline 1961 & 52.0 & 56.5 & 54.6 & 64.1 \\
\hline 1962 & 51.4 & 55.9 & 54.5 & 64.0 \\
\hline 1963 & 51.3 & 55.6 & 54.3 & 63.3 \\
\hline 1964 & 51.8 & 55.9 & 54.5 & 63.1 \\
\hline $\begin{array}{l}1965 \\
1966\end{array}$ & $\begin{array}{l}52.4 \\
53.3\end{array}$ & $\begin{array}{l}56.1 \\
56.5\end{array}$ & $\begin{array}{l}55.1 \\
56.0\end{array}$ & $\begin{array}{l}62.7 \\
62.6\end{array}$ \\
\hline 1967 & 53.4 & 56.4 & 56.4 & 62.5 \\
\hline 1968 & 53.1 & 56.0 & 56.2 & 62.3 \\
\hline 1969 & 54.4 & 57.2 & 57.5 & 63.3 \\
\hline 1970 & 57.8 & 60.6 & 61.1 & 66.9 \\
\hline 1971 & 61.1 & 63.4 & 65.5 & 70.5 \\
\hline 1972 & 66.5 & 68.2 & 71.2 & 74.7 \\
\hline $\begin{array}{l}1973 \\
1974\end{array}$ & $\begin{array}{l}76.2 \\
89.8\end{array}$ & $\begin{array}{l}76.8 \\
89.6\end{array}$ & $\begin{array}{l}79.3 \\
88.2\end{array}$ & $\begin{array}{l}80.6 \\
87.7\end{array}$ \\
\hline 1975 & 100.0 & 100.0 & 100.0 & 100.0 \\
\hline 1976 & 102.3 & 102.8 & 102.7 & 103.5 \\
\hline 1977 & 109.9 & 109.1 & 110.5 & 109.1 \\
\hline 1978 & 125.4 & 122.6 & 126.8 & 121.5 \\
\hline 1979 & 141.7 & 136.5 & 139.2 & 129.7 \\
\hline 1980 & 157.7 & 153.0 & 153.6 & 145.0 \\
\hline 1981 & 151.7 & 150.1 & 149.7 & 146.6 \\
\hline $\begin{array}{l}1982 \\
1983\end{array}$ & $\begin{array}{l}147.3 \\
143.4\end{array}$ & $\begin{array}{l}148.1 \\
144.5\end{array}$ & $\begin{array}{l}147.8 \\
145.5\end{array}$ & $\begin{array}{l}149.1 \\
147.6\end{array}$ \\
\hline 1984 & 138.5 & 139.6 & 140.9 & 142.8 \\
\hline 1985 & 139.0 & 139.9 & 142.1 & 143.7 \\
\hline 1986 & 168.5 & 169.5 & 173.5 & 174.9 \\
\hline 1987 & 191.1 & 192.0 & 196.1 & 197.2 \\
\hline 1988 & 207.4 & 208.0 & 208.1 & 208.9 \\
\hline
\end{tabular}




\section{Notes to Appendix Table B19}

For the indexes labeled "Adjusted for U.S. Only," the U.S. indexes for SITC 7 from Table B17 are combined with the indexes for other countries in the same way as for Tables BI through B4.

For the indexes labeled "Adjusted for All Countries," each U.S. hedonic price index was substituted for the conventional price index for that particular SITC subgroup or group at the three or, usually, four digit SITC level for inserted where there had been no conventional index) in the index for every country. The individual country indexes for all manufactures and the world indexes were then aggregated, as in earlier tables. To prevent the hedonic adjustment from affecting uncovered groups and subgroups, the substitution was performed by subtracting the unadjusted indexes from the SITC aggregate and adding back the adjusted indexes with the same weights. Where no unadjusted index existed for a group or subgroup, the subtraction was done assuming that the uncovered items had the same price index as SITC 7 as a whole. 
$=66-$

APPENDIX C

Indexes Based on Export Weights of the U.S., Germany, and Japan 
Appendix Table $\mathrm{Cl}$

Price Indexes for Manufactured Exports by the U.S. and its Competitors, U.S. Dollars

U.S. Export Weights of 1963

(Annua 1 Averages, 1975=100)

\begin{tabular}{|c|c|c|c|}
\hline & $\begin{array}{l}\text { U.S. } \\
\text { Export } \\
\text { Prices }\end{array}$ & $\begin{array}{c}\text { Indexes } \\
\text { Domestic } \\
\text { Prices }\end{array}$ & $\begin{array}{l}\text { Rest-of-Wor } 1 d \\
\text { Price Index }\end{array}$ \\
\hline 1953 & 50.9 & 48.0 & 46.3 \\
\hline 1954 & 51.5 & 48.6 & 45.8 \\
\hline 1955 & 52.1 & 50.1 & 46.2 \\
\hline 1956 & 54.9 & 52.4 & 47.2 \\
\hline 1957 & 57.5 & 54.7 & 48.1 \\
\hline 1958 & 58.5 & 55.5 & 47.8 \\
\hline 1959 & 59.3 & 56.6 & 47.4 \\
\hline 1960 & 60.2 & 57.0 & 47.5 \\
\hline 1961 & 61.1 & 57.0 & 48.5 \\
\hline 1962 & 61.6 & 57.1 & 48.1 \\
\hline 1963 & 62.2 & 57.2 & 48.3 \\
\hline 1964 & 63.1 & 57.6 & 49.1 \\
\hline 1965 & 63.7 & 58.3 & 50.0 \\
\hline 1966 & 64.8 & 60.1 & 51.2 \\
\hline 1967 & 67.0 & 61.7 & 51.2 \\
\hline 1968 & 69.0 & 63.6 & 50.2 \\
\hline 1969 & 71.5 & 65.4 & 51.6 \\
\hline 1970 & 73.3 & 68.1 & 55.3 \\
\hline 1971 & 76.9 & 70.3 & 59.2 \\
\hline 1972 & 79.1 & 72.0 & 65.5 \\
\hline 1973 & 81.8 & 74.8 & 75.7 \\
\hline 1974 & 90.0 & 87.5 & 88.8 \\
\hline 1975 & 100.0 & 100.0 & 100.0 \\
\hline 1976 & 106.1 & 105.6 & 101.6 \\
\hline 1977 & 112.7 & 112.1 & 110.7 \\
\hline 1978 & 118.5 & 119.9 & 127.8 \\
\hline 1979 & 129.4 & 133.2 & 148.5 \\
\hline 1980 & 143.3 & 148.6 & 167.8 \\
\hline 1981 & 157.6 & 164.1 & 154.0 \\
\hline 1982 & 169.3 & 169.5 & 147.3 \\
\hline 1983 & 173.8 & 173.1 & 142.1 \\
\hline 1984 & 178.4 & 177.6 & 134.4 \\
\hline 1985 & 179.1 & 179.2 & 135.3 \\
\hline 1986 & 181.6 & 179.9 & 170.3 \\
\hline 1987 & 187.4 & 184.2 & 199.2 \\
\hline 1988 & 198.3 & 194.9 & 218.8 \\
\hline
\end{tabular}


Appendix Table $\mathrm{C} 2$

Price Indexes for Manufactured Exports by Germany and its Competitors, U.S. Dollars

German Export Weights of 1963

(Annual Averages, 1975=100)

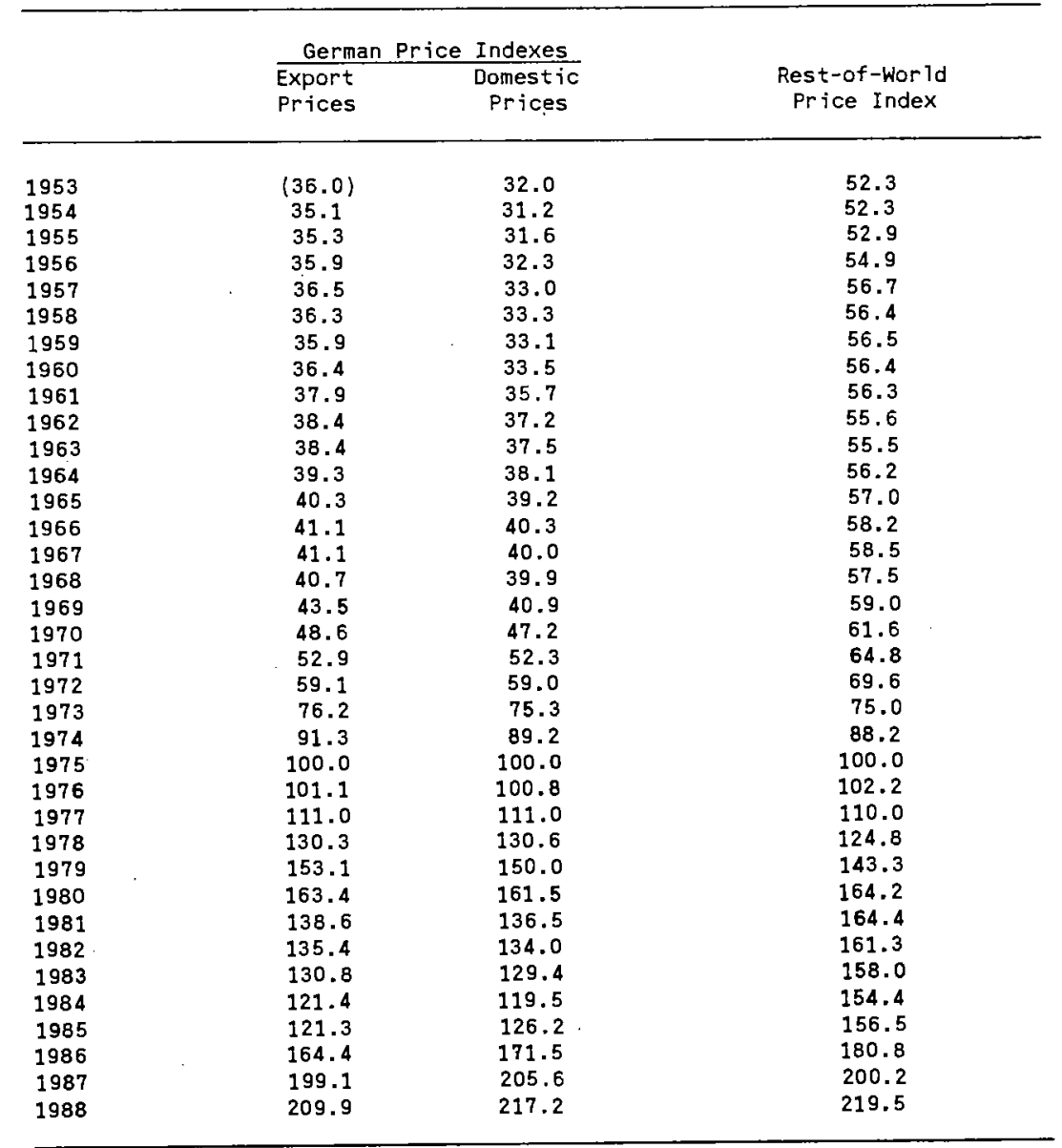


Appendix Table $\mathrm{C3}$

Indexes for Manufactured Exports by Japan and its Competitors, U.S. Dollars Japanese Export Weights of 1963

(Annua) Averages, $1975=100$ )

\begin{tabular}{|c|c|c|c|}
\hline & $\begin{array}{l}\text { Japane } \\
\text { Export } \\
\text { Prices }\end{array}$ & 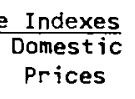 & $\begin{array}{l}\text { Rest-of-World } \\
\text { Price Index }\end{array}$ \\
\hline 1953 & 63.0 & 58.1 & 50.3 \\
\hline $\begin{array}{l}1954 \\
1955\end{array}$ & $\begin{array}{l}59.6 \\
58.4\end{array}$ & $\begin{array}{l}54.9 \\
53.5\end{array}$ & $\begin{array}{l}50.0 \\
50.6\end{array}$ \\
\hline 1956 & 61.4 & 57.4 & 51.5 \\
\hline 1957 & 60.9 & 57.9 & 52.7 \\
\hline 1958 & 55.0 & 53.8 & 52.5 \\
\hline 1959 & 56.8 & 54.3 & 52.0 \\
\hline 1960 & 57.2 & 54.6 & 52.0 \\
\hline 1961 & 54.9 & 53.8 & 52.4 \\
\hline 1962 & 53.2 & 52.8 & 51.7 \\
\hline 1963 & 53.7 & 53.1 & 51.6 \\
\hline 1964 & 54.5 & 53.3 & 52.3 \\
\hline 1965 & 54.3 & 53.2 & 53.1 \\
\hline 1966 & 53.8 & 53.4 & 54.1 \\
\hline 1967 & 54.4 & 53.8 & 54.0 \\
\hline 1968 & 55.1 & 54.2 & 53.4 \\
\hline 1969 & 56.8 & 55.7 & 54.7 \\
\hline 1970 & 58.6 & 58.3 & 58.2 \\
\hline 1971 & 60.1 & 59.7 & 61.7 \\
\hline $\begin{array}{l}1972 \\
1973\end{array}$ & $\begin{array}{l}65.9 \\
81.6\end{array}$ & $\begin{array}{l}67.4 \\
86.0\end{array}$ & $\begin{array}{l}67.1 \\
76.4\end{array}$ \\
\hline $\begin{array}{l}1974 \\
1975\end{array}$ & $\begin{array}{l}100.0 \\
100.0\end{array}$ & $\begin{array}{l}101.4 \\
100.0\end{array}$ & $\begin{array}{r}90.2 \\
100.0\end{array}$ \\
\hline 1976 & 102.8 & 105.9 & 101.4 \\
\hline 1977 & 108.4 & 119.0 & 109.2 \\
\hline 1978 & 130.3 & 153.9 & 123.6 \\
\hline 1979 & 137.5 & 151.9 & 139.8 \\
\hline 1980 & 147.6 & 159.4 & 157.3 \\
\hline 1981 & 152.7 & 164.6 & 150.2 \\
\hline 1982 & 140.6 & 145.5 & 147.4 \\
\hline 1983 & 138.9 & 154.4 & 143.0 \\
\hline 1984 & 139.8 & 155.8 & 137.6 \\
\hline 1985 & 137.7 & 155.1 & 139.1 \\
\hline $\begin{array}{l}1986 \\
1987\end{array}$ & $\begin{array}{l}168.0 \\
186.3\end{array}$ & $\begin{array}{l}212.7 \\
241.0\end{array}$ & $\begin{array}{l}165.2 \\
186.3\end{array}$ \\
\hline 1988 & 210.1 & 272.1 & 200.6 \\
\hline
\end{tabular}


Appendix Table C4

Price Indexes for Manufactured Exports by

the U.S. and its Competitors, U.S. Dollars

U.S. Export Weights of 1975

(Annual Averages, 1975=100)

\begin{tabular}{|c|c|c|c|}
\hline & $\begin{array}{c}\text { U.S. } \\
\text { Export } \\
\text { Prices }\end{array}$ & 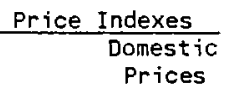 & $\begin{array}{l}\text { Rest-of-Wor 1d } \\
\text { Price Index }\end{array}$ \\
\hline 1953 & 54.6 & 48.3 & 48.1 \\
\hline 1954 & 55.3 & 48.9 & 47.5 \\
\hline 1955 & 56.0 & 50.2 & 47.7 \\
\hline 1956 & 59.0 & 52.6 & 48.7 \\
\hline 1957 & 62.0 & 55.2 & 49.7 \\
\hline 1958 & 63.0 & 56.2 & 49.1 \\
\hline 1959 & 64.0 & 57.2 & 48.6 \\
\hline 1960 & 65.0 & 57.6 & 48.6 \\
\hline 1961 & 66.0 & 57.6 & 49.4 \\
\hline 1962 & 66.2 & 57.6 & 48.8 \\
\hline 1963 & 66.5 & 57.5 & 49.0 \\
\hline 1964 & 67.1 & 57.8 & 49.6 \\
\hline 1965 & 67.6 & 58.4 & 50.5 \\
\hline 1966 & 68.9 & 60.0 & 51.6 \\
\hline 1967 & 71.2 & 61.8 & 51.6 \\
\hline 1968 & 73.1 & 63.6 & 51.0 \\
\hline 1969 & 75.5 & 65.3 & 52.2 \\
\hline 1970 & 76.6 & 67.9 & 55.7 \\
\hline 1971 & 80.0 & 70.4 & 59.5 \\
\hline 1972 & 81.6 & 72.0 & 65.9 \\
\hline 1973 & 84.1 & 74.4 & 76.6 \\
\hline 1974 & 92.1 & 86.5 & 89.0 \\
\hline 1975 & 100.0 & 100.0 & 100.0 \\
\hline 1976 & 106.2 & 105.6 & 101.7 \\
\hline 1977 & 112.6 & 112.3 & 110.5 \\
\hline 1978 & 117.3 & 120.4 & 127.8 \\
\hline 1979 & 127.3 & 132.9 & 146.2 \\
\hline 1980 & 141.1 & 148.5 & 162.4 \\
\hline 1981 & 154.6 & 163.2 & 150.7 \\
\hline 1982 & 165.4 & 169.7 & 144.1 \\
\hline 1983 & 170.9 & 172.8 & 139.7 \\
\hline 1984 & 175.7 & 176.9 & 132.5 \\
\hline 1985 & 177.1 & 178.5 & 133.4 \\
\hline 1986 & 179.5 & 179.2 & 169.4 \\
\hline 1987 & 184.9 & 183.0 & 196.9 \\
\hline 1988 & 194.9 & 192.2 & 214.1 \\
\hline
\end{tabular}


Appendix Table C5

Price Indexes for Manufactured Exports by Germany and its Competitors, U.S. Dollars German Export Weights of 1975

(Annual Averages, $1975=100$ )

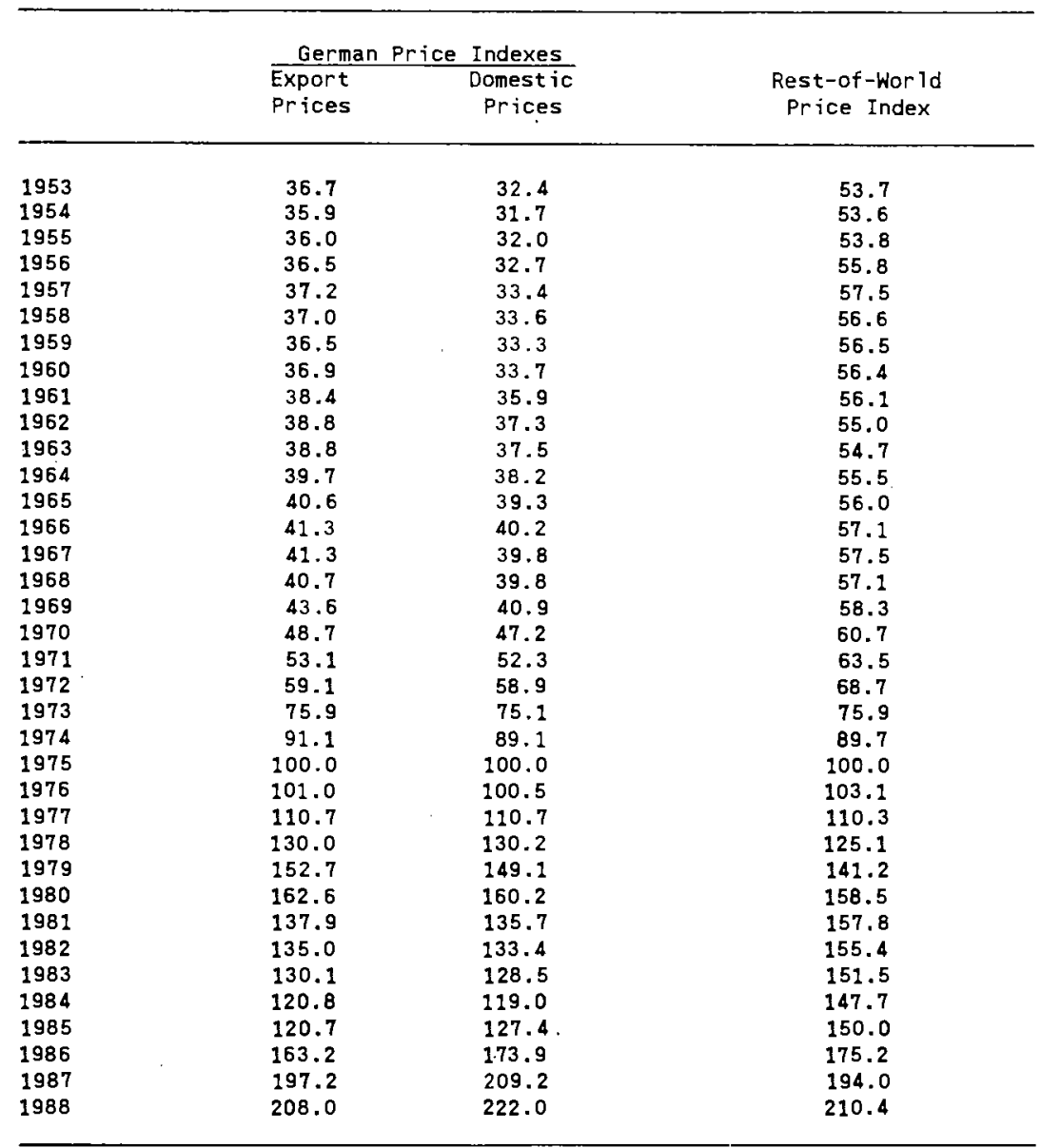


Appendix Table C6

Price Indexes for Manufactured Exports by

Japan and its Competitors, U.S. Dollars

Japanese Export Weights of 1975

(Annual Averages, $1975=100$ )

Japanese Price Indexes

$\begin{array}{lcc}\text { Export } & \text { Domestic } & \text { Rest-of-World } \\ \text { Prices } & \text { Prices } & \text { Price Index }\end{array}$

\begin{tabular}{|c|c|c|c|}
\hline $\begin{array}{l}1953 \\
1954\end{array}$ & $\begin{array}{l}64.6 \\
60.2\end{array}$ & $\begin{array}{l}71.0 \\
67.6\end{array}$ & $\begin{array}{l}49.4 \\
49.1\end{array}$ \\
\hline 1955 & 60.0 & 66.1 & 49.7 \\
\hline 1956 & 64.5 & 70.7 & 50.8 \\
\hline $\begin{array}{l}1957 \\
1958\end{array}$ & $\begin{array}{l}65.2 \\
57.3\end{array}$ & $\begin{array}{l}71.4 \\
66.3\end{array}$ & $\begin{array}{l}52.1 \\
52.1\end{array}$ \\
\hline 1959 & 58.4 & 65.8 & 51.4 \\
\hline 1960 & 58.4 & 64.9 & 51.0 \\
\hline $\begin{array}{l}1961 \\
1962\end{array}$ & $\begin{array}{l}56.5 \\
54.7\end{array}$ & $\begin{array}{l}63.3 \\
61.5\end{array}$ & $\begin{array}{l}51.2 \\
50.6\end{array}$ \\
\hline $\begin{array}{l}1963 \\
1964\end{array}$ & $\begin{array}{l}54.0 \\
54.8\end{array}$ & $\begin{array}{l}60.7 \\
60.3\end{array}$ & $\begin{array}{l}50.2 \\
50.7\end{array}$ \\
\hline 1965 & 54.8 & 59.7 & 51.3 \\
\hline 1966 & 54.4 & 59.6 & 52.3 \\
\hline 1967 & 54.6 & 59.8 & 52.3 \\
\hline 1968 & 54.9 & 59.1 & 51.9 \\
\hline 1969 & 56.4 & 59.8 & 53.4 \\
\hline 1970 & 58.3 & 61.3 & 57.3 \\
\hline 1971 & 60.1 & 62.6 & 61.2 \\
\hline 1972 & 65.6 & 69.5 & 66.4 \\
\hline 1973 & 78.8 & 84.0 & 75.1 \\
\hline 1974 & 100.5 & 99.9 & 88.8 \\
\hline 1975 & 100.0 & 100.0 & 100.0 \\
\hline 1976 & 99.4 & 104.2 & 101.4 \\
\hline 1977 & 103.5 & 117.4 & 107.9 \\
\hline $\begin{array}{l}1978 \\
1979\end{array}$ & $\begin{array}{l}125.3 \\
131.4\end{array}$ & $\begin{array}{l}151.5 \\
147.7\end{array}$ & $\begin{array}{l}122.6 \\
138.4\end{array}$ \\
\hline $\begin{array}{l}1980 \\
1981\end{array}$ & $\begin{array}{l}138.9 \\
145.9\end{array}$ & $\begin{array}{l}152.1 \\
156.2\end{array}$ & $\begin{array}{l}154.4 \\
146.1\end{array}$ \\
\hline 1982 & 134.1 & 137.3 & 144.0 \\
\hline 1983 & 133.0 & 145.4 & 139.4 \\
\hline 1984 & 134.2 & 146.7 & 134.0 \\
\hline 1985 & 131.8 & 145.2 & 135.6 \\
\hline 1986 & 157.8 & 199.4 & 163.4 \\
\hline 1987 & 175.3 & 226.1 & 185.0 \\
\hline 1988 & 197.9 & 254.4 & 198.8 \\
\hline
\end{tabular}

